\title{
Energy Strategy: \\ Roadmap to Consensus
}

\section{DISCLAIMER}

\begin{abstract}
This report was prepared as an account of work sponsored by an agency of the United States Government. Neither the United States Government nor any agency thereof, nor any of their employees, makes any warranty, express or implied, or assumes any legal liability or responsibility for the accuracy, completeness, or usefulness of any information, apparatus, product, or process disclosed, or represents that its use would not infringe privately owned rights. Reference herein to any specific commercial product, process, or service by trade name, trademark, manufacturer, or otherwise does not necessarily constitute or imply its endorsement, recommendation, or favoring by the United States Government or any agency thereof. The views and opinions of authors expressed herein do not necessarily state or reflect those of the United States Government or any agency thereof.
\end{abstract}

\section{a report from the \\ Board of Directors of the American Energy Assurance Council}

on

\section{the substance and process of the National Energy Consensus Experiment}

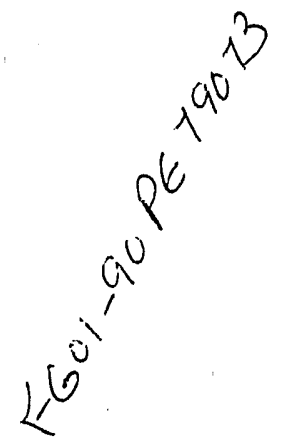

CONVENED to IMPROVE AMERICA'S CAPACITY FO COOPERATION

November, 1990 
DOE/PE/ $79073--T 2$

DE92 007910

\section{TABLE OF CONTENTS}

Introduction

page 3

Executive summary

page 5

The National Energy Consensus Experiment
A. Preparation
B. The session
C. Table results: summaries
D. Process lessons

page 7

page 9

Preparation

page 11

Negotiation

page 20

page 23

Follow-up

page 27

Appendices
A. "Must-have" topics list
B. "Must-haves" with policy options
C. Annotated verbatim table reports
D. Options matrix: table by table
E. Process-oriented commeritaries
F. List of NECE participants
G. AEAC Board of Directors
H. Management Team and Staff
I. Project Sponsors 


\section{INTRODUCTION}

The United States lacks a comprehensive approach to policy-making in the energy realm. Today, as in the past, individual constituency groups tend to focus on their particular aspect of the energy challenge. Many employ a "decide-announcedefend" approach to policy-making, setting out to secure a unilateral advantage ior themselves. By so doing, they inevitably pit interest against interest. The result is a polarization of constituencies, and shortsighted policies designed to address the issue of the moment.

As energy questions continue to be addressed on a case-by-case basis, events on the global level sway and skew the decision-making process. The occasional sharp discontinuity (for example, the fall of a government overseas) precipitates a "crisis," in response to which ad hoc policies -- many of them internally inconsistent -- are pieced together. Longer-term trends, despite their overriding importance, are consistently obscured.

As this report is being written, our nation is experiencing an abrupt reawakening to the realities of energy supply and demand. The Iraqi invasion of Kuwait has underscored our renewed and increasing reliance on foreign oil. This is a dramatic example, but it is not an isolated example. In fact, many energy sources now present us with either volatile pricing, questionable availability, or both. At the same tirve, environmentail concerns are mounting. Most informed observers agree, therefore, that there are many combinations of current trends and behaviors that could precipitate an energy crisis.

As a result of this ever-present threat, there is an emerging consensus among the competing constituency groups that the interconnected nature of energy-related policies must be acknowiedged. There is growing sentiment that all interested parties share the need for constructive dialogue. Adversaries of long standing now appear willing to work tugether to jointly shape a solution which provides for all affected parties.

The American Energy Assurance Council (AEAC) is a non-profit organization founded for the sole purpose of facilitating progress toward a fair, efficient, wise, stable, and consensus-based national energy strategy. When AEAC was founded in 1987, we were convinced that the national energy problem was a significant challenge that had to be met. In the three intervening years, as we have sponsored several consensis-building activities, we have only become more convinced of the urgency of this challenge. Our national energy problems -- economic, environmental, consumer, and security-related -- have grown in scale and scope. They are without question among the most compelling issues facing our nation today. 
AEAC does not have a substantive policy agenda. Rather, we are committed to supporting a process whereby the many stakeholders and policy makers concerned with energy-related issues can come together in productive discourse, thereby overcoming ignorance of each other's positions. We believe that it is important that representatives from all interested parties convene, in a spirit of cooperation and with a shared commitment to a common goal. The Council seeks to act as a facilitative body, providing a "safe" context for inventive and creative thinking. We attempt to build a store of common knowledge, and to build on that store according to mutually agreed-upon groundrules, and employing sophisticated approaches to facilitation and mediation.

This report from the AEAC Board of Directors summarizes the third stage of our activities: the National Energy Consensus Experiment (NECE). The NECE was an ambitious experiment in consensus-building. We learned a great deal from it, both in terms of substance and process, and we are convinced that it holds important lessons for others who may seek to build consensus in the public policy realm. 


\section{EXECUTIVE SUMMARY}

The NECE was the second of two large-scale experiments in consensusbuilding conducted by AEAC. (For details on both of these experiments, see the following section.) In the context of the NECE, AEAC brought together an "unlikely coalition" of 126 senior-level executives from twelve energy stakeholder groups, for a one-and-a-half-day intensive negotiating session. This session was held in May 1990 at Princeton, New Jersey.

The twelve stakeholder groups met in caucus, first identifying energy-related topics important to their respective constituencies (see Appendix A), and then agreeing upon policies that addressed those topics (see Appenidix B). Next, eight negotiating tables were set up, with one representative from each stakeholder group sitting at each of the eight tables. The tables attempted to arrive at "packages" of "elegant trades," whereby the key needs of each stakeholder group would be met. These packages were presented to the entire group in verbatim table reports (see Appendix $C$ and Appendix D). The packages, and the participants' interpretations of them, are summarized in this report.

Our assessment of the NECE is, on balance, very positive. First, the caucus process gave us a very clear picture of "must-have" topics that will need to be reflected in any successful and enduring national energy strategy. It also suggested the policy choices that the stakeholders felt would serve those needs.

The negotiations themselves presented many "process" problems (see pages 19-25); and given the inherent time constraints, the packages arrived at by the participants tended to be general in nature. Nevertheless, they represent an important preliminary step toward the development of consensus on energy issues. Adversaries met, discussed, found unexpected common ground, experimented with the "trading" approach, and (in most cases) left the NECE with a strong inclination to continue the experiment.

Each participant and each constituency group at the NECE has a different interpretation of its substantive outcome. The AEAC board, moreover, is firm in seeing the NECE as an interim step. Based on our observations, the verbatim table reports, and numerous follow-up letters and conversations, however, we can make the following observations:

-- Concern about national dependence on imported oil had diminished (at least in comparison with the opinions expressed at our November, 1988, consensusbuilding experiment, and before the Iraqi invasion of Kuwait). 
-- Concern about international competitiveness has grown (again, in comparison with the opinions expressed at our earlier experiment).

-- There is essentially no opposition to stronger conservation policies, and there is significant interest in linking rewards for energy conservation and least cost planning by utilities. (In August of 1990, the California Public Utilities Commission approved such an approach for that state, based on a plan devised -- according to the Wall Street Journal -- by "an unusual coalition of energy companies, consumer groups, industry associations, and regulators.") More generally, there is widespread interest in rewarding both producers and users for taking cost-effective efficiency measures.

-- There is general agreement that market-based approaches, both on the supply side and the demand side, should be emphasized (although a minority view held that any domestic effort to explore for new hydrocarbon reserves will flounder without a support mechanism). Although much work would have to be done in order to create a widely acceptable mechanism to reflect externalities to markets, this appears to be a very promising area for joint work by interested parties.

-- There is a perceived need for increased orderliness and predictability in the regulatory process (although various tables advocated different ways to achieve this end).

-- There is widespread agreement on the need for more basic research in a number of technology areas, including clean coal technologies and the improvement and standardization of nuclear power plant design. Surprising to many participants was the agreement on the need to preserve the nuclear energy option.

-- Consensus did not emerge on certain key issues, including, for example: oil and gas exploration on Federal holdings; nuclear energy and waste disposal; mass transit; CAFE standards and guzzler/sipper incentives; the transmission, pricing, and use of natural gas; and the assessment of (and action on) global climate change. However, each of these topics was discussed at length at a majority of the negotiating tables. This suggests that these issues, as well as others suggested by the frequency of their appearance in the attached table-by-table matrix (see Appendix $D)$, must be considered in any comprehensive national energy policy.

These are interesting provisional results. The AEAC board would like to stress, however, that it has been the consistently positive response of NECE participants -- as much as the subsiantive results reached at the tables -- that has encouraged us to bring these findings to a wider audience. 


\section{THE NATIONAL ENERGY CONSENSUS EXPERIMENT}

\section{A. Preparation}

In order to understand the process and outcome of the National Energy Consensus Experiment, it is helpful to understand its antecedents.

In 1988, AEAC sponsored an energy-crisis simulation exercise in Leesburg, Virginia. Participants at the National Energy Policy Simulation (NEPS) were transported to 1993, where they confronted an escalating energy crisis. Each participant was assigned a role, and given a packet of confidential information explaining his or her situation and responsibility -- either as a member of the "Presidential Commission" charged with resolving the crisis, or as a lobbyist seeking to influence the process.

The session commenced with a "documentary" news program, showing footage of unrest in the Middle East (which was causing price shocks in the U.S.), reports from the White House and Wall Street, and editorial commentary by the "network." (Verisimilitude was enhanced through the use of well-known news personalities.) Members of the Commission then convened in a meeting room to negotiate, and lobbyists met in a larger room, where they watched the negotiating session on closed-circuit TV.

"Six months" of negotiations were compressed into 23 hours of real time. Throughout the negotiations, the Commission session was periodically opened to the lobbyists for testimony and questions. Both lobbyists and commission members were exposed regularly to media commentaries on the progress (or lack of progress) of the Commission.

The most interesting development at Leesburg occurred when the lobbyists, as a group, grew impatient with the slow progress of the Commission. Acting on this frustration, they aligned themselves into two "mega-caucuses": one representing consumers, environmentalists, and alternative energy groups; and the other comprised of representatives from farming, the coal, nuclear and oil and gas industries, industrial consumers, and auto companies. These two groups worked independently for most of the afternoon, assembling packages of policies that met their respective needs. Toward the end of this session, the two groups compared lists, and spent the final part of the afternoon questioning and educating one another on their respective stances.

The Commission, meanwhile, was proving unable to reach consensus on a policy parkage of its own. Its members did agree on a number of general principles defining an appropriate approach to energy policy. But the overall message of the 
NEPS was clear: if and when a real energy crisis arises, it will already be too late to shape a fair, efficient, wise, and stable energy policy.

Based in part on the Leesburg experience, AEAC next developed a comprehensive survey on energy issues: Options for a National Energy Strategy. This survey generated responses from more than 200 senior-level energy stakeholders, and provided us with a clearer understanding of which policies, issues, and options are most important to each of 12 constituency groups.

The final pre-NECE step was a series of focus groups with members of each of the 12 constituencies. The information obtained through these two exercises served as the substantive basis for the NECE. 


\section{B. The session}

The NECE was designed as a structured framework of discussion and debate, intended to bring together the many energy stakeholders, most of whom were "locked into" adversarial positions, and allow them to be inventive.

The design included small position-assessment caucuses organized by interest group; large plenar; sessions, in which commonalities and differences of opinion were to be presented to the entire group; and negotiation sessions, in which one or two members from each constituency met in a relatively small group and discussed possible areas of agreement, and potential opportunities for "trades" across issues. The framework was intended to provide enough time for participants to assess their own arguments and the arguments of others, and to build a common base of information.

In the initial caucus session, constituency groups identified five topics (either chosen from a supplied list or invented by the caucus) which they felt should be included in the agenda for a national energy strategy. They identified two of these topics as "must-haves," without which their group's interests could not be served.

The separate caucuses then met in a plenary session, where the "must-have" topic list was presented, amended, and approved as the agenda for further discussion (see Appendix A).

Interest groups subsequently returned to their caucuses, and spent time examining the agenda and suggesting potential policies to represent their positions on those issues. (Policies were either selected from the AEAC's supplied list, or invented by the participants.) The resulting "must-have" topics list, with attached policies, is included at the end of this report (see Appendix B). This caucus session was followed by a second plenary session, during which the lists of options generated by all groups were compiled as a starting point for the negotiations to follow.

A final caucus session enabled each constituency group to examine all the options suggested by the group as a whole, and to plan a strategy for negotiation. While the individual caucus members were expected to represent only themselves -and not a caucus "party line" -- in negotiations, most caucus members found it useful to settle on key priorities as a group, and to anticipate the priorities that other stakeholders might present.

The caucus groups then dissolved, with at least one member from each caucus heading for each of eight negotiating tables. Most tables, therefore, included between twelve and eighteen participants, whose activities were observed by a 
number of foundation and media representatives. (The media ground rule observed throughout the NECE was that no one could be quoted by name.)

The negotiating tables all employed different approaches, depending on the participant mix and the skills and orientation of the facilitator. The assignment at all eight tables, however, was to seek out and package "elegant trades" across issues. (In other words, Participant A agrees to include Policy 1 -- which s/he sees as relatively unimportant -- in a package of policies, in exchange for Participant B agreeing to include Policy 2, which s/he sees as extremely important. Participant B, meanwhile, places a high value on Policy 1 , and a low priority on Policy 2.)

According to participants at most of the tables, little progress was made in the early stages of negotiation, with most of the progress being compressed into the final hours and minutes of the talks. (This dynamic is typical of time-bound negotiations.) Sorne tables proved highly skilled at negotiating and packaging; others proved less so. Most participants agreed that time limits prevented "trading" at any level of detail. All eight tables, however, avoided deadlocks, and produced reports that were shared with all NECE participants in a final plenary session. 


\section{Table results: summarles}

In the following pages, we attempt to summarize briefly the substance of the negotiations conducted at the eight NECE negotiation tables. (For an overall summary of the process issues identified through the NECE, see the following section: "Process lessons.")

These table-by-table summaries resulted from the verbatim reports of the eight tables and, in part, the written assessments generated after the NECE: letters, surveys, and so on. Readers interested in the comprehensive results generated at the tables are strongly encouraged to refer to the verbatim reports (see Appendix C). 


\section{Table 1}

Members of Tabie 1 began their session with an exercise which was intended to promote creative thinking about packages of policy options. Each participant was asked to write a proposed national energy strategy from the point of view of the Secretary of Energy. Members of the group then reviewed and commented upon each other's proposals. Some participants criticized this approach as being too time-consuming and productive of generalities and platitudes, rather than of real trading across issues.

Following this exercise, members of the group then proposed five general areas which could be used as an overall topic guideline: global context, marketdriven realities, efficiencies, environment, and supply.

A number of policies (between five and eleven) were then suggested under each of those headings. These included: a commitment to US leadership by example on energy in the global context, encouraging other countries by action and support through technology and information, with safeguards that no action should jeopardize US competitiveness; creating a truly fair and competitive market by eliminating barriers to efficiency, creating a level playing field, and implementing incentives for energy-efficient choices; taking action to improve the environmental effects of energy production/consumption; and adjusting the present energy situation to create a more stable and diverse energy supply that is not only efficient, but also cost- , security-, and future-conscious.

Of these options, roughly half were agreed upon as the basis for an emerging consensus, but the remaining options would have required further negotiation and revisions in wording to have been incorporated into an overall agreement. The group modified an existing policy option to read: "Provide incentives to internalize environmental and other external costs," but some participants cautioned that specific measures would prove harder to agree upon.

Time limits kept this group from compiling a list of options they considered adequate for a comprehensive national energy strategy. Several participants felt strongly that the needs of certain constituency groups (for example, the gas producers and distributors) were not adequately understood or accommodated. After the session, some participants saw unexpected common ground on the subject of an emissions tax, and thought this might have been a point of consensus if time had not run out. 


\section{Table 2}

Early in the negotiation session at Table 2, one member -- a representative of the environmental caucus -- suggested an overall framework within which to conduct the discussion, but the group as a whole rejected what they saw as an inherently lin ited approach.

Instead, the participants each ranked a list of topics that they felt were important to a national energy strategy, and the group then systematically worked on an "agenda" consisting of the highest-ranking topics. The discussion that followed produced some viable suggestions, but also underscored a measure of disagreement and tension among the participants. One reason for these problems was that the key concerns of several participants (including, for example, nuclear energy and mass transit) were not included on the provisional agenda.

Several hours arid many arguinents later, the environmental representative again suggested his framework, this time exp'anded to include a sample package of options, some of which had been suggested in the preceding discussions. Other participants proposed additional options, and the group packaged together fourteen policies, six of which were newly created or significantly modified from the supplied agenda. Collectively, these sketched out a strategy which comprised: the allocation of research funds; mass transit; alternatively fueled vehicles; nuclear energy; improved operation of utilities; foreign and domestic oil; international competition; and environmental action.

Among the amended/created options were: prioritize programs at National Labs to be consistent with the National Energy Strategy, and significantly increase R\&D funds to universities; investigate alternative fuels for fleets in urban areas; provide access to federally-regulated lands for coal, oil, and gas exploration, development, and production, consistent with environmental regulations; require integrated resource planning for electric utility companies; and create incentives for secondary and tertiary development of oil and gas fields.

Several participants later observed that conservation was the unexpected common ground at this table. On the other hand, representatives from: producer states felt that representatives from consumer states were uninformed on key issues -- such as the relative economic impact of oil import fees -- and that this effectively precluded consensus on these issues. 


\section{Table 3}

Negotiation Table 3 compiled an extensive list of policy options under seven general categories: Electricity (Utility Regulatory Reform), Oil and Gas, National Security, Clean Coal Technologies, Nuclear, and Public Education. Each of the seven categories was considered as a "package" of trades; arid together, the seven packages were conceived of as an overall package of integrated trades for a national energy strategy.

The electricity package recommended a combination of revisions to present regulations and the creation of incentives to promote efficient energy production. Consensus on policies for oil and gas was impeded by a protracted debate about the definition of "environmentally sensitive lands," but eventually embraced thirteen policies ranging from domestic oil regulations, exploration, and recovery methods to auto use and increased gasoline and diesel taxes. Policies included in the national security package advocated a diverse energy mix, as well as US action that improves international standards without jeopardizing competitiveness. Group 3 also endorsed the promotion of clean coal technologies to combat global climate change, and its nuclear package concentrated on 1) funding for research to improve plant design and 2) nuclear waste management. Finally, the participants at this table agreed that public education on energy economics was necessary to the national energy strategy.

In a number of cases, the group modified the supplied agenda options to propose policies which better reflected their concerns -- among them: provide tax incentives for enhanced recovery on existing fields; de-couple utility profits from kilowatt hours; and promote international emergency planning. 


\section{Table 4}

The initial attempts to generate a package at Table 4 broke down into stalemate. After a period of generally unproductive disagreement -- during which several participants left the table in frustration -- a subset of the participants generated a rough "package" of ideas. These ideas, in turn, inspired a list of general principles.

Gradually, the group worked toward consensus on these basic principles, which included: a tocus on energy efficiency, self-financing mechanisms for any new initiatives, improved standards of living, minimal regulation linked to the creation of incentives for voluntary participation, and measures to promote equity for disparate constituents. Together, these were the cornerstones of an energy policy intended to take into account four key components: 1) energy efficiency, 2) the environment, 3) the economy, and 4) national security.

Next, the group undertook to construct policy packeiges that addressed each of these four component parts. Representatives from this table objected to any substantial "distillation" of these carefully constructed packages; the reader, therefore, is referred to the annotated verbatim report of Table 4 (see Appendix C).

All told, the group suggested more than 30 policies, many newly created or modified in combinations, as building blocks of a national energy strategy. In retrospect, several participants at this table expressed surprise at how little attention was focused on oil and gas, and on the needs of producers and distributors in these industries. 


\section{Table 5}

At a relatively early stage, members of Table 5 framed their discussion in a way that ultimately served as their policy-package structure. The framework described the overall energy challenge as having three component narts: Energy Use, Energy Supply, and Reduced Fuel Consumption. Ultimately, combinations of policies were devised within and across these broad headings, in an effort to address the needs of all energy stakeholder groups.

The "energy use" package sought to assure a diverse mix of energy sources (including oil, gas, renewables, nuclear, electric). It also suggested actions to promote efficiency, both in the form of incentives and of fair and stable regulations for those energy sources. Finally, policies included in this package were intended to improve international energy practice in light of U.S. competitive, security-related, and environmental issues.

Suggestions under energy supply included: promoting international safety and environmental standards; allowing stationary source emissions trading; streamlining of gas transmission; and addressing vulnerability. (The group did not reach consensus on how to accomplish this last issue.)

Reduced furel consumption -- the third component part of Table. 5's framework -- was addressed through the endorsement of stringent CAFE standards, increased motor vehicle fuel taxes with the resulting revenue dedicated to funding mass transit, incentives for purchasing energy-efficient cars, and increased funds for renewable sources, energy efficiency, conservation, and technology transfer. 


\section{Table 6}

Table 6's policy packages encompassed five broad topic areas, as follows:

First, eight policies were combined to create a "utility policies" package. These were designed to reform utility regulation, while providing incentives to make a least-cost plan the utility's most profitable; and to encourage more efficient production and use of energy.

Second, a package of energy supply policies embraced the Strategic Petroleum Reserve (SPR), adequate oil-refining capacity, domestic oil exploration and production (OCS drilling regulation), nuclear plant design and waste management, and assurances for a diversity of fuel supplies.

Third, Table 6 linked environmental and transportation issues in a package designed to modify automobile use with increased CAFE standard and guzzler/sipper incentives while simultaneously providing increased funding to mass transit; together, these steps were aimed at reducing $\mathrm{SO} 2$ levels.

Fourth, a group of four policies related to research and development provided guidelines for fund allocation in nuclear and fusion energy, clean coal technologies, renewables, and technology transfer and efficiency.

Finally, a consumer package supported citizen edication on energy economics, and a system to protect vulnerable groups (elderly, handicapped, and low income) from potential repercussions of amended energy policies. 


\section{Table 7}

At the beginning of Table 7's negotiations, one participant presented a proposed "philosophical starting-point." In effect, this statement asserted that energy conservation, efficiency, and regulatory reform had to serve as the cornerstones of a national energy strategy. The statement's proponent then advocated several policies that seemed to support this philosophical approach. Principal among these policies was least-cost planning, with externalities and uncertainties considered.

As ensuing negotiation touched on a variety of topics, it became clear that, issue by issue, two or three voices tended to dominate each discussion. In order to facilitate packaging within the time allotted, therefore, the group discussed issues only to the point where the broad outline of a policy package became apparent. At that point, a subgroup moved outside the roon to devise a policy package, which was subsequently presented to the group as a vhole for clarification and ratification.

In all, five such packages were "ratified" for inclusion in the final agreement.

The "international cooperation on energy and environment" package recommended that the US take an energy leadership role in the world -- but by example, rather than through direct aid or coercion -- without creating a threat to national economic competitiveness. On a related topic, the group's "competitiveness and fiscal soundness" package combined maximizing domestic energy production with measures to improve the level of world energy, environmental, and economic standards. Due to time limitations, the natural gas package included only one recommendation: improving the economics of riatural gas exploration, production and development.

The nuclear package endorsed nuclear prower as an option for baseload electricity, vith a number of caveats and qualifiers attached. There is some disagreement as to the actual wording that was agreed upon; for a summary of these discrepancies, the reader is referred to the verbatim report of Table 7 in Appendix C.

Finally, the "national security and imported oil vulnerability" package combined the establishment of a Strategic Petroleum Reserve and standby authority for release of reserves with policies to alter consumer transportation habits, to be achieved by an increase in CAFE standards and gas and diesel taxes, which would collectively provide incentives for mass transit. 


\section{Table 8}

Participants in the negotiations at Table 8 began their work by identifying one "must-have" topic. The group then set out to find ways to reflect those particular issues in ways acceptable to all members of the group. The result was a collection of eight policy packages on which they reached a general consensus.

The group agreed in principal to preserve all energy options that would contribute to an environmentally safe and economically viable energy policy. Increased federal R\&D to enhance energy efficiency received general support.

Table 8's participants declared themselves in favor of mitigating vulnerability to, but accepting dependency on, oil imports. They agreed that a national energy policy had to differentiate between vulnerability and dependence.

Federally regulated lands -- although not wilderness lands or national parks -could be opened to exploration, but only after conservation and efficiency measures were in place, and existing supplies were being used efficiently.

The group agreed to preserve nuclear energy as an option for baseload electricity if it could be made safe, environmentally sound, and cost effective. Group members also advocated a comprehensive, consensus-based public participation process, including the development of standards and criteria to generate public acceptance of the nuclear option.

To reduce the consumption of fuels, the group suggested a combination of steps: an increase in CAFE standards, implementation of a guzzler fee/sipper rebate, and an increase in federal gasoline and diesel taxes with partial rebates to states and to the oil and gas industries. They would redirect funds in the existing clean coal technologies program to focus on energy efficiency and $\mathrm{CO} 2$ emissions (including basic research and a pilot program). 


\section{Process lessons}

It is important to remember that the NECE was originally conceived as an experiment -- and that it is still an experiment. AEAC assembled its unlikely coalition, and began its three years of explorations, with an underlying premise: that consensus-building might be a useful tool in the development of a national energy policy. This premise was tested first at Leesburg, in a simulation exercise. A year and a half later, it was tested again at Princeton.

The current sense of the board is that consensus-building can make an important contribution in this realm. In order for future efforts to have their greatest impact, however, we must carefully review the process lessons we have learned in Stages I through III.

Leesburg was our first "process model." Princeton, our next experiment, in many ways represented a departure from the procedures followed at Leesburg. Comparing these two experiences has helped us to understand more about the positive things that happened at Leesburg: what worked, and why? Similarly, when contrasted with Leesburg, which aspects of Princeton worked, and which did not?

Following is a compilation of the process lessons identified by the board, with the help of those who participated in either Leesburg or Princeton, or both. These lessons are organized into three categories: preparation, negotiation, and follow-up. While the lessons have been derived from the specific context of the NECE, we suspect that many of them have important implications for future consensus-building efforts in the public policy realm.

\section{Process lessons: preparation}

The overriding process challenge has to do with the effective use of time. NECE participants almost unanimously conciuded that one and a half days aren't enough time to make real progress toward consensus. At the same time, most acknowledged that senior-level people could riot be expected to commit more than two or three consecutive days -- or more than a finite number of days overall -- to negotiations.

Why is more time needed?

First, the caucus process (both before and during negotiations) is invaluable. If it is compressed, the negotiation process suffers.

Second, the scale and scope of the energy agenda means that negotiators must come to grips with an array of complex issues that are not normally raised 
concurrently. While no single negotiator will become an expert in all substantive areas, each must learn enough to have confidence that he or she understands what is at stake, issue by issue. This educational process takes time, at and away from the table.

Third, the negotiations themselves are time-consuming. In addition, participants need time to meet with their caucus members, to meet informally with members of other constituent groups, and perhaps to check back with their constituents.

For these and other reasons, the AEAC board endorses a new approach to scheduling, substantially different from both Leesburg and Princeton. At a minimum we advocate two full-scale "packaging" sessions, of approximately two days each. These would be separated by approximately a month, and would be preceded and followed by extensive staff work. Frequent caucuses would take place for the duration of this process.

Such a schedule would not place unrealistic demands on senior-level participants, and would probably give negotiators enough time to yield the fullest measure of consensus possible. It would avoid the pressure inherent in a "one-shot" process.

The definition of stakeholder groups is extremely important, and is also very difficult to get exactly right. In retrospect, we are rethinking some of the alignments defined in advance of Princeton. It may be impossible, for example, to assemble a meaningful "financial" caucus, since the financial community includes so many disparate groups. For similar : easons, the "national security" group was inclined to dissolve itself at Princeton, and probably should not be reconstituted in that form. These caucuses may be better reflected in the "gatekeeper" presence of policymakers responsible for calculating policy impacts on the economy and on national security.

It appears that the "oil" and "gas" caucuses should be redivided into oil and gas independents, oil and gas majors, and gas transmission/LDCs. The various subcategories of our "consumer" group also need more effective representation. Finally, it should be noted that several important constituencies were missing from Princeton -- most notably, the automobile companies. (For the record, AEAC repeatedly tried to persuade any or all of the major U.S. and foreign auto manufacturers to participate in the process.) Participating constituent groups should not have to imagine the needs and views of absent groups; and most participants agreed that the absence of key groups from the negotiating tables had a negative impact at Princeton. 
Within stakeholder groups, the quality of representation is critical. Caucus participants, in other words, must understand and be able to articulate their interests. Uneven representation at the caucus level is likely to impede progress at the negotiation stage, by rendering a given caucus less effective relative to other caucuses.

Once defined, stakeholder groups should caucus well in advance of face-toface negotiations. One early goal should be to identify a caucus leader. Based on those prenegotiation meetings, stakeholder groups should also select their own representative(s) for the negotiations. This representative may or may not be the same individual as the caucus leader.

Leesburg was initiated by means of a videotaped "simulation." The face-toface negotiations at Princeton, by contrast, were preceded by an extended surveyand-focus-group sequence. While NECE participants had the benefit of a preliminary agenda, derived from the survey and focus groups and backed up with extensive documentation, many ultimately wanted more.

Specifically, they felt the need for a more focused product as a starting point for negotiations. (AEAC had, in fact, prepared a conflict assessment, focus-group write-ups, and various technical summaries in advance of the NECE, but .- in the interest of not "prewiring" the outcome -- did not broadly distribute much of this material. For example, each constituent group received only a summary of the focus group findings in that particular interest area.) In the preparation stase, therefore, a "product" for focusing discussion should be defined and generated by the process managers.

For example: such a product might include a clearer sense of the options that might be on the table at the negotiation stage. What materials can be prepared, and/or briefings held, to get people excited about the prospect of negotiation?

Consensus building on the national level necessarily brings together stakeholding groups with very different levels of tactical experience in negotiating allgain agreements. There is a clear potential for imbalanced negotiations when groups experienced in consensus building sit down with groups more accustomed to other kinds of bargaining. Therefore, some or all stakeholder groups may need "coaching," in the sense of process advice, in advance of negotiations. Coaches, preferably selected by each group, would assist the groups in preparing their respective negotiating strategies. 


\section{Process lessons: negotiation}

If coaching is needed in the preparatory stage, it should probably continue in the negotiation stage. Our sense is that many participants at Princeton did not fully understand what the consensus-building process would demand from them. Coaches could stress (for example) the importance of inventing options, and help particlpants differentiate between "inventing" and "committing." This could help overcome a serious prelliminary challenge -. the invention of provisional packages -and help the negotiators move on to the major task at hand: improving those packages.

On a related point, participants need to "buy off" on the process of working together. To a certain extent, this can only be achieved through successes at the table. But constituent-group coaches could facilitate this process in the early stages of negotiation, at least until a sustaining level of trust has been built up at the table.

Creative scheduling should be used to "break the lce." All scheduling should be designed to facilltate (whether directly or Indirectly) caucusing and coalitionbullding. Obviously, events such as meals and breaks must be included; but these should be designed as complements to negotiation.

The number of participants, and negotiating tables, is an important consideration. We have identified a basic tension on this point. On the one hand, there is safety in parallellsm. (It is better to have more than one table, in case the interpersonal dynamics at the single table go awry.) On the other hand, most participants at the NECE felt that in total, there were too many people involved. And since many of these same partlcipants felt that more constituent groups needed representation at the table, rather than fewer, we conclude that the solution lies in fewer tables. One table may be too few; elght tables (as at Princeton) is probably too many.

Before negotiations begin, two key process issues have to be addressed. First, the responsibilities of the negotiation managers should be articulated and ratified. Second, the ground rules governing the negotiation need to be agreed to by all stakeholding groups before the negotiating process begins. At Princeton, the perception of changes in the ground rules led to disaffection among some groups. Although negotlations are not fundamentally a democratic process, negotiation managers must avoid even the appearance of arbitrariness.

Specifically: what are the rules that will govern 1) caucuses, 2) plenary sessions, and 3) negotlations? What constitutes "voting"? Will time limits on speaking be determined? Once these protocols are established, they must be 
rigorously enforced.

At the same time, a degree of informality and flexibility should be built into the overall process. For example, participants in the Leesburg process cited the importance of the casual interactions between various constituent groups. (At Leesburg, all constituent groups caucused at indlvidual tables in one large room, promoting dialogue among the groups. At Princeton, by contrast, caucuses were held behind closed doors.) Throughout the negotiating process, there needs to be a mechanism for informal meetings and excharinges of views between constituent groups.

This "structured informality" would benefit: not only the caucus process, but also the negotlations. It would help defuse the "eight-glass-boxes" syndrome that many found counterproductive at Princeton. It would also ensure that negotlators become increasingly aware of other constituent-group perspectives, in relaxed contexts away from the table. If and when caucuses with common interests begin to "aggregate" voluntarily -- as was the case at Leesburg -- this tends to have a productive impact on the communications flow, and oventually on the negotiations.

At this relatively early stage, the desired level of specificity of the policy options to be incorporated in the final agreemerits should also be discussed. Will it be enough, for example, to agree to higher CAll=E standards, or will it be necessary to determine specific levels? (How specific?) if an agreement specifies that ANWR lands are to be opened to oil exploration, does that agreement also have to specify which lands, and under what conditions? We generally believe specificity should be at the level where all questions have been asked, answered, and agreed upon.

We have already suggested that stakeholder groups should select their own representatives for the negotiations. Based on the Princeton experience, where at least some participants felt "maroonea"' or isolated, we conclude that each negotiator should be supported by an informed group, perhaps sitting behind the individual at the table. Only that individual would be authorized to speak, but he or she could consult at any time with members of an informed, alert, and like-minded support group. Staff support should also be avallable to each of the negotiating parties.

A consistent suggestion from NECE participants was that facilitators at the negotiating tables should have a way of understanding, and therefore keeping up with, the substantive issues being discussed. Expertise in facilitation is obviously crucial, as is the facilitator's professional neutrality. But at the same time, "elegant trades" might be more easily discovered if .- for example -- the facilitator had extensive knowledge of the complex issues being discussed. Because it may prove difficult to find facilitators with both process skills and substantive backgrounds, it may be necessary to structure facilitating "teams" in any future negotiations. 
In such cases, professional facilitators could collaborate with "substance experts." Prenegotiation sessions, attended by both, would serve two important ends. First, the "process experts" -- the faclitators -- would begin their education in the substantlve issues, and would contribute to shaping the negotiation process. Second, the substance experts would begin to be sensitized to the inherent process complexities of the upcoming negotiations.

The negotlations themselves should be protected from any outside influence that inhibits free expression and participation. Based on the Princeton experience, we conclude that media representatives should be excluded from the negotiation sessions. For the same reasons, the number and activities of observers should be carefully monitored.

We recognize that media interest in events like Princeton is high, and also that media coverage can have beneficial impacts. (The David Broder column that summarized the Princeton experience, for example, led directly to expressions of interest from major stakeholders who had previously declined to participate in the consensus-building process.) A reasonable compromise would be to bar media coverage until negotiations were complete. Participants could then hold joint press conferences to meet the needs of the media.

The negotiation process should not conclude without all participants receiving a written version of what their negotiations achieved. This summary statement should comprise both what was included and what was not included in the agreement. Participants should be asked to initial this summary. "Pressure tactics" should be avoided, since they are likely to lead to unrealistic and unstable agreements. (At Princeton, for example, some participants felt that time pressures, and other pressures to "settle," gave a de facto veto power -- and therefore undue influence -- to individual negotiators.) On the other hand, participants should know in advance that they will be expected to commit themselves publicly, "in or out," to the final document summarizing the consensus policy packages. This should help ensure that participants will eventually "play their trump cards," and minimize the sense that the negotiations are "only a game."

All negotiation sessions should end with short debriefings, allowing participants to go on record -- out loud, and in front of each other -- with their personal evaluation of the results. Participants should be accountable to each other. They should be prepared to give honest evaluations of how they view the consensusbuilding process and its accomplishments.

In any case, a sense of closure is important. It is not satisfactory simply to run out of time, and have participants leaving to catch planes. The risks inherent in 
this haphazard wind-down are twofold: first, that valuable lessons may be lost; and second, that the negotiation output may be accidentally trivialized. 


\section{Process lessons: follow-up}

The follow-up stage should therefore begin before negotiators leave the site of the last packaging session. Both participants and sponsors should be asked for two kirids of input. First, they should make suggestions about potential applications of the specific policy recommendations to which they've agreed. Second, they should comment on the process: what worked, and what didn't?

All of this "captured" data should be retained and organized for eventual interpretation. (Whenever possible, flip-chart tearsheets, overheads, and worksheets should also be retained.) The Princeton experiment suggests to us, however, that negotiation managers and sponsors should not rush to judgment on the value of the process. In the wake of a challenging and stimulating experience such as a highlevel negotiation, each individual's perceptions of the process are likely to continue to evolve for days or weeks.

Of course, strong proponents and detractors of the process tend to make their views knowin to the sponsors of the effort, in person, by phone, or by mail. But as noted above, those views may or may not be long-lasting. Negative comments in particular should be carefully weighed. They may or may not reflect majority opinion, or even the individual's overall opinion.

For example: two weeks after the NECE, we conducted a follow-up phone survey of the dozen-or-so strongest detractors of that experiment. While they remained consistent in their criticisms of certain aspects of Princeton, all but one advocated additional consensus-building negotiations. This countered our expectations, based on earlier communications.

Again based on the Princeton experiment, we conclude that a follow-up mail survey to all participants is an important step. There was a surprising degree of overlap among the process suggestions elicited through that survey. Many of those suggestions have been incorporated in our design to continue the search for common ground on national energy strategy. 


\section{APPENDICES}

While our several consensus-building experiments have generated volumes of information, much of it interesting, we will include only nine appendices of particular interest. (A cover sheet preceding each appendix explains its contents.)

They are:

Appendix A: $\quad$ "Must-have" topics list

Appendix B: "Must-haves" with policy options

Appendix C: $\quad$ Annotated verbatim reports, Tables 1-8

Appendix D: Options matrix: table by table

Appendix E: $\quad$ Process-oriented commentaries

Appendix F: $\quad$ Lists of NECE Participants, and

12 Constituent Groups

Appendix G: $\quad$ AEAC Board of Directors

Appendix $\mathrm{H}$ : $\quad$ Management Team and Staff

Appendix I: $\quad$ Project sponsors 


\section{APPENDIX A: "MUST-HAVE" TOPICS LIST}

This is the "must-have" topics list generated in the first caucus session. In the opinion of the AEAC board, this is the smallest possible "universe" of key issues to be included in a national energy policy. 


\section{Topics Which Must $\mathrm{Be}$ Included in the National Energy Strategy Agenda}

Motor vehicle usage

Strategic Petroleum Reserve

Imported oll

Federally regulated oil and gas exploration on federal holdings

Exploration and development for new domestic oll and gas fields

Natural gas transmission and use

Energy conservation, load management, and efficiency: all fuels

Nuclear energy

Renewable energy supply

Clean coal technologies

Air toxics and other air emissions

Consumer welfare

Competitiveness and fiscal soundness

Energy allocation pollcy

Assured electricity supply

Assured energy supply

Utility regulatory reform

Economies for natural gas production, exploration, and development

Energy R\&D/technology transfer

End-use energy efficiency (all vehicle efficiency/end-use)

Structural reform of industry/regulation

International cooperation

Nuclear proliferation (international)

Global climate change

Energy conservation, efficiency, and least cost planning

Internalization of environmental and other external costs

Energy production, refining, and distribution infrastructure 


\section{APPENDIX B: "MUST-HAVES" WITH POLICY OPTIONS}

This is the topic list expanded by the twelve caucuses to include appropriate policy options. The policies marked with asterisks are either new, or substantially modified versions of AEAC-supplied policies. (Nearly a hundred of these substantially new policies were invented at the caucus tables.) Collectively, these policies served as the base-line for the negotiations that followed, although the participants were free to invent additional pollcy options as necessary.

The organization of these topics and related policy options is an outgrowth of the original survey structure. That survey comprised seven major topic areas:

-- transportation fuels

-- domestic oil and gas supply

-- electricity supply

-- air quality

-- global climate change

-- water quality and land ecology, and

... economic issues.

The organization of these topics and options also reflects the negotiating process. New policy options (again, those asterisked policies created during the negotiations) are included at the end of the various topic areas. 
2. Motor Vehicle Usage

2F. Increase federal gasoline and diesel fuel tax by $\$ 1.00-2.00 /$ gallon -1

$2 \mathrm{G}$. No increase in gasoline/diesel fuel taxes -- 1

$2 \mathrm{H}$. Increase federal funding levels for mass transit -- 2

2I. Provide tax and/or other incentives for business mass transit programs -2

2L. Increase CAFE standards to $35-40$ mpg by $2000-1$

20. Eliminate disincentives to mass transit -3

2P* Require use of electric vehicle fleets in urban areas

$2 Q^{*}$ Require least-cost planning for all vehicle transportation usage

\section{Strategic Petroleum Reserve [SPR] (National Security)}

[IEA: International Energy Agency]

4B. Lease oil and/or oil reserves as alternatives to SPR purchases -1

4C. Create a separate reserve for refined oil products -- 1

4F. Eliminate or privatize the SPR -- 1

4I. Limit SPR petroleum sales to qualified domestic refiners -- 1

4K. Encourage increased SPRs in other IEA countries -- 2

\section{Imported Oil}

5D. No import source restrictions -- 3

5 H. No import fee --2

5J* Mitigate vulnerability (but accept dependency)

$5 \mathrm{~K}^{*}$ Limit imports to some percentage of total domestic production

Legend:

Numbers preceding policy options correspond to the pre-NECE scoping survey, and were used to identify them for discussion. The numbers after policy options indicate how many caucus groups recommended that that option be included for discussion in the negotiation session at the NECE.

Asterisks indicate options which were newly created, or significantly modified from the survey, in the caucus session. 
6. Federally Regulated Oil and Gas Exploration on Federal Holdings

[OCS: Outer Continental Shelf offshore regions; ANWR: Alaska National Wildlife Refuge]

6C. Set OCS environmental regulation on an area-specific basis -- 1

6G. Set ANWR environmental regulation on an area-specific basis --1

6I. Open onshore, designated lower- 48 federal lands under existing environmental restrictions -- 1

6Q. Maximize U.S. oil and gas output from existing fields, and bar any development of environmentally-sensitive lands - 1

$6 \mathrm{R}^{*}$ Open federally regulated lands under existing conditions

6S* Predictable, long-term rules about availability of federal lands

6T* Share existing royalties on production with state and local governments

$6 \mathrm{U} *$ Stabilize regulatory environment for oil and gas exploration

$6 \mathrm{~V} *$ Economic incentives for proving new reserves

\section{Exploration and Development of New Domestic Oil and Gas Fields}

7B. Provide an investment tax credit for exploration, development and products -- 1

7F. Fund R\&D in advanced exploration methods -- 1

7G. Provide tax incentives for domestic oil and gas exploration, development and recovery -2

\section{Natural Gas Transmission and Use} [FERC: Federal Energy Regulatory Commission; LNG: Liquid Natural Gas]

12A. Streamline licensing process for natural gas pipeline construction -- 1

$12 \mathrm{E}$. Adopt rate design reforms that encourage efficient use of pipeline capacity and storage -- 1

Numbers preceding policy options correspond to the pre-NECE scoping survey, and were used to identify them for discussion. The numbers after policy options indicate how many caucus groups recommended that that option be included for discussion in the negotiation session at the NECE.

Asterisks indicate options which were newly created, or significantly modified from the survey, in the caucus session. 


\section{Renewable Supply Sources}

[PURPA: Public Utilities Regulatory Policy Act]

18A. Increase $R \& D$ funding for renewables -- 1

18D. Create tax credits for the purchase and use of renewable energy equipment -1

18J* Increase R\&D funding for renewables provided new revenues are available from some tax

$18 \mathrm{~K} *$ Require all source bidding, including environmental externalities

$18 \mathrm{~L}^{*}$ Increase $\mathrm{R} \& \mathrm{D}$ and demonstration, emphasizing long-run best buys

$18 \mathrm{M}^{*}$ Increase use in federal facilities

$18 \mathrm{~N}^{*}$ Demonstrate biofuels as tool for sustainable farming and forestry

180* Streamline permitting for renewables (including hydro-pump storage)

\section{6/28. Air Toxics and Other Air Emissions from Stationary Sources}

[BACT: Best Available Control Technology; CA Standard: current California ozone non-attainment area standards for discharge of $\mathrm{NO}_{\mathrm{x}}, \mathrm{SO}_{2}$, and VOCs; Critical areas: not in attainment of air quality standards; EPA: Environmental Protection Agency; MMS: Merchant Marine Service (?)]

26B.Require BACT for expanded definition of sources (e.g., $>5$ tons/yrtsingle; $>15$ tons/yr multiple) -- 2

26L. No change in existing regulation -- 1

28I.* Consumption tax on carbon-emitting fuels

$28 \mathrm{~J} *$ Emission $\$$ to imported fuels

$28 \mathrm{~K} *$ Emission reduction 10-12 utility/industry

$28 \mathrm{~L}^{*}$ Legislation to encourage and fund CCTs

\section{Energy Allocation Policy: Crisis Contingency Planning}

39A. Develop plans, based on international energy cooperation, to assure coordinated energy preparedness -- 4

39E. Do nothing but allow price shocks to take care of energy supply allocation -- 1

39F* Allow market forces to take care of energy supply allocation

39G* Develop coordinated state and federal catastrophic shortage contingency plan

Legend:

Numbers preceding policy options correspond to the pre-NECE scoping survey, and were used to identify them for discussion. The numbers after policy options indicate how many caucus groups recommended that that option be included for discussion in the negotiation session at the NECE.

Asterisks indicate options which were newly created, or significantly modified from the survey, in the caucus session. 


\section{Nuclear Energy}

15A. Preserve nuclear energy as an option for baseload electricity -- 3

15C. Streamline licensing process for nuclear energy plants -- 4

15D. Standardize nuclear energy plant designs -- 3

15E. Increase $R \& D$ on advanced nuclear energy plant designs -- 2

15L* Increase R\&D on advanced nuclear energy plant designs and fusion energy with designs that are appropriate for competing in world energy markets

$15 \mathrm{M}^{*}$ Standardize nuclear energy plant designs and operations

\section{Power Plant Approval and Construction}

16B. Limit scope of prudence reviews -1

16D. Allow Construction Work In Progress (CWIP) in the rate base -- 1

$16 \mathrm{~F}$. Integrate siting and permitting into a one-step process -2

16G. Replace prudence reviews with CWIP reviews -- 1

16L. Establish a "site bank" for future utility needs -- 1

160. Allow life of facility permitting -- 1

16P* Integrate construction and operating licensing into one-step process

$16 Q^{*}$ Develop comprehensive consensus-based public participation process

$16 R^{*}$ Process to expedite environmental, legal, and regulation approval process

\section{Clean Coal Technologies (CCTs)}

[ITC: Investment Tax Credit]

19K. Expedite environmental permitting process for CCTs -- 1

19M. Extend Clean Air Act compliance time via waivers for CCTs -1

19Q* Extend current R\&D funding level/increase funding for commercial demonstration and deployment of CCTs

\section{Assured Electricity Supply}

41A. Preserve nuclear energy as an option for baseload electricity -- 1

41B. Provide open transmission access -- 1

41C. Establish site banks for future utility power plant needs -- 1

41E. Assure a stable and predictable regulatory process over the long term (10-15 years) -- 3

$41 \mathrm{~F} *$ Preserve all fuels as options

41G* Stable regulatory process

$41 \mathrm{H}^{*}$ Obligation to serve requires utility decisions on supply and delivery options

41I* National energy policy that says nuclear is a significant part of the energy mix and federal barriers are removed

Numbers preceding policy options correspond to the pre-NECE scoping survey, and were used to identify them for discussion. The numbers after policy options indicate how many caucus groups recommended that that option be included for discussion in the negotiation session at the NECE.

Asterisks indicate options which were newly created, or significantly modified from the survey, in the caucus session. 


\section{Utility Regulatory Reform}

43B. Provide financial incentives to utilities for conservation and load management programs -- 1

43D* Allow CWIP in the rate-base

43E* Replace end-of-construction prudence revlews with rolling prudence reviews or periodic CWIP reviews

43F* Decouple profits from sales -- reward efficient investment

43G* Develop procedures and incentives for utilities to provide transmission access

43H* Encourage market-based regulation in generation of electricity

43I* Promote common carrier operation of transmission systems

43J* Develop utility profits from kilowatt hours

\section{Competitiveness and Fiscal Soundness}

[RD\&D: Research, Development and Demonstration]

36D. Increase overall level of federal R\&D funding in energy $\ldots 1$

36G. Reallocate federal R\&D funds from national labs to university and private labs -.. 1

36I* Maximize the use of domestic resources

36J* Encourage the passage of environmental standards in foreign countries

$36 \mathrm{~K}^{*}$ Put mobility as primary use priority for liquid fuels

36L* Expand R\&D tax credits

$36 \mathrm{M}^{*}$ Balance federal budget; control inflation; improve savings and incentives for capital investment

36N* Assess and revise laws which negatively impact international competitiveness of US products

360* Improve international industrial competitiveness through policies and programs that take into consideration economic competitiveness, the environment, and energy supplies.

36P* Ensure that cost-effectiveness and international competitiveness be considered in any major federal action

\section{The Economics of Natural Gas Production, Development, and Exploration*}

47A* Encourage long-term contracts and mutuality of obligations

47B* Provide a price for natural gas which will exceed the replacement cost for new reserves.

Legend:

Numbers preceding policy options correspond to the pre-NECE scoping survey, and were used to identify them for discussion. The numbers after policy options indicate how many caucus groups recommended that that option bo included for discussion in the negotiation session at the NECE.

Asterisks indicate options which were newly created, or significantly modified from the survey, in the caucus session. 


\section{Energy R\&D/Technology Transfer}

52A* Create tax credits for purchase and use of renewable energy equipment

52B* Fund R\&D and commercialization for renewable/efficient energy technologles

$52 C^{*}$ Increase R\&D funding in energy efficiency

52D* Increase technological transfer, commercialization and demonstration

$52 E^{*}$ Reduce and reallocate R\&D funds for fusion

$52 F^{*}$ Expand to 50\% the fraction of civilian R\&D budgets of DOE, EPRI and GPI devoled to conservation and renewables; emphasize applied research including social sciences

$52 \mathrm{G}^{*}$ Include modest demonstrations of advanced technologies with best prospects of long-run least-cost including externalites

$52 \mathrm{H}^{*}$ Support industrial energy R\&D centers of excellence

\section{End-use Energy Efficiency (all vehicle efficiency/end-use)*}

$53 \mathrm{~A}^{*} 40 \mathrm{mpg}$ plus \%

$53 \mathrm{~B}^{*}$ Gas sipper

53C* CAFE standards to 4() $45 \mathrm{mpg}$

53D* Tighten appliance and building efficiency standards

53E* Develop strategy for an effective mass transit system (funded by oil import fee and gas tax)

53F* Adopt efficient auto package: $40 \mathrm{mpg}$ CAFE by 2000; $\$ 1 / \mathrm{gal}$ gas tax phased in over 5 years; revenue neutral guzzler/sipper tax rebate with $+1-\$ 200 / \mathrm{mpg}$ slope

53G* Establish industrial R\&D centers of excellence for generic technologies

$53 \mathrm{H}^{*}$ Establish ratings and standards for industrial equipment including lights and motors

531* Provide adequate financial incentives for demand-side initiatives

\section{Structural Reform of Industry Energy and Environment *}

NOTE: No new options proposed

\section{International International Cooperation on Energy and Environment}

59A* US takes leadership role in fashioning international standards for energy development and use and environmental protection with monitoring and enforcement mechanisms.

59B* US does not take unilateral action which would have long-term competitive disadvantage.

Numbers precoding policy options correspond to the pre-NECE scoping survey, and were used to Identify lliem for disoussion. The numbers after policy options indicate how many caucus groups recommonded that that option be included for discussion lis the negotiation session at the NECE.

Asterisks indicate options which were newly created, or significanlly modified from tho survey, in the caucus session. 


\section{Nuclear Proliferation (international)}

$65 \mathrm{~A}^{*}$ Stop international reprocessing

$65 \mathrm{~B}^{*}$ Strengthen control on sensitive technology exports

\section{Address Global Climate Change}

72A* Actions on global climate change should be integrated on an international basis

72B* Encourage and initiate CCT on international basis; where applicable promote renewable energy/least-cost energy plan

$72 \mathrm{C}^{*}$ International research efforts on global climate change should integrate both scientific and economic impact

72D* Negotiate an international agreement to reduce global emissions to $25 \%$ below 1985 levels by 2025

72E* Negotiate an international agreement to reduce global emissions to $50 \%$ below 1985 levels by 2025

72F* Promote renewable energy, cogeneration, and energy efficlency technologies abroad

$72 \mathrm{G}^{*}$ Help other countries initiate least-cost energy planning processes

$72 \mathrm{H}^{*}$ Fund R\&D on CO2 impacts

72I* Fund R\&D on new CO2 reduction technologies

\section{5/75. Consumer Welfare and Education}

35A. Provide conservation subsidies for elderly, handicapped, and low income groups -- 1

35C. Establish relocation/retraining funding and programs for displaced energy industry workers $\ldots 1$

$35 \mathrm{~F}^{*}$ Citizen education on energy economics

35G* Conservation subsidies and financial incentives

\section{Energy Conservation, Efficiency, and Least-cost Planning $(\# 14$ \& \#17 R) *}

14G. Use a conșumption tax to pay for energy conservation programs -- 1

14K. Tighten appliance and building efficiency standards -1

17P. Require least-cost planning for gas and utility companies -- 1

17Q. Reform utility regulations to make the least-cost plan the utility's most profitable plan -1

Numbers preceding policy options correspond to the pre-NECE scoping survey, and wore used to identify them for disoussion. The numbers after policy options indicate how many caucus groups recommonded that that option be included for discussion in the nogotiation session at the NECE.

Asterisks indicate options which were newly created, or significantly modifiel from the survey, in the caucus session. 


\section{Appendix B \\ "Must Haves" with Polloy Options}

\section{Internalize Environmental and Other External Costs (\#37 R)*}

37F. Allow stationary source emission trading -1

37J* Market mechanisms for enforcement of environmental standards

$37 \mathrm{~K}^{*}$ Provide incentives to substitute domestic gas for imported oil

37L* Require least-cost plan

$37 \mathrm{M}^{*}$ Carefully quantify costs and benefits and put tax at point of cost

$37 \mathrm{~N}^{*}$ Use taxes and standards to incorporate environmental and energy security costs

\section{Energy Production, Refining, and Distribution Infrastructure *}

78A* Ensure adequate refining capacity and import receiving facilities

78B* Ensure future electrical supply

78C* Rationalize liability exposure

78D* Endorse bubble concept

78E* Level playing field for marketing and distribution

\section{Nuclear Energy (addendum)}

15G* Continue and facilitate safe, on-site spent-fuel storage; accelerate siting and construction of a permanent repository and a centralized federal monitored retrievable storage facility for spent fuel.

41 J* Nuclear energy is a significant part of the energy mix

$15 \mathrm{~N}^{*} \quad$ Establish a self-financing independent federally-chartered corporation to manage storage of the nation's commercial nuclear waste

\section{Utility Regulatory Reform (addendum)}

43X* Amend PUCA to facilitate competition in wholesale service with level playing field for registered holding companies and recognition for consumer protection

43Y* Reestablish federal preemption over wholesale transactions

43Z* Revise FERC regulations and state law so that decisions made by a commission are binding on future commissions except for just cause shown

Legend:

Numbers preceding policy options correspond to the pre-NECE scoping survey, and were used to identify them for discussion. The numbers after policy options indicate how many caucus groups recommended that that option be included for discussion in the negotiation session at the NECE.

sujterisks indicate options which were newly created, or significantly modified from the survey, in the caucus session. 


\section{APPENDIX C: ANNOTATED VERBATIM TABLE REPORTS}

The table reports are reprinted exactly as they were turned in by the negotiating tables. After the NECE, we received many substance-oriented comments from participants. We added these comments, in itallc type, to the reports.

The commentaries underscore the fact that even some "agreements" may not represent consensus. They also emphasize that time constraints may have led to inaccuracies in reporting -- not so much in misstatements of the reported agreements, but in fallures to incorporate all areas of consensus in the verbatim reports. 


\section{Verbatim Report of Negotlation Table \#1 to Plenary Session NECE, May 22, 1990 6:00 pm}

Members of this group included: a US governor and administrators from government agencies; industrial consumer representatives; representatives of the oil, electricity, coal industries; a representative from the transportation sector; administrators of environmental organizations; members of the academic community; and an attorney.

5 General Areas

- global context

- market driven

- efficiencies

- envirorrment

- supply

* Identified principles first, then started in specifics

* Question marks show items on which there is not yet unanimity

* Many question-marked items were very close to unanimity and would probably make it if more discussion could occur - word-smithing was needed

* But some question marks represent continuing disagreements

\section{Global Context}

? U.S. leadership in cooperative agreements on energy and the environment - but don't get so far ahead that we put ourselves

"This option needed wordsmithing hut had potential to be agreed upon"

"We can't shoot ourselves in the foot"

- Provide technology to the world to serve: global security; development; environment

? The best way to be a leader is by example - can't invite others to do things we're not doing ourselves

"This had potential with some work on the words"

- Support research to assess global climate issue

\footnotetext{
"Negotiation group demonstrated that poople coming together can work. There was enough substance there, and enough agreement. Shows that DOE has a position to say 'we de have a blessing to move forward with the following:' If they recognize that they have a winning hand, we'll get something out of it. Let them lay claim to it - bring it in - use outsiders' credibility to their advantage." collective discomfort. Clarifying examples killed off confusion, and thus, killed off consensus. We didn't tackle a list; we went conceptually. First thing: two natural gas guys got into argument. Environmentalists pounced. The resulting 'trades' weren't a package, but a microcosm of the whole effort of the morning session."
} 
- Do the "no regrets" things

- Comprehensive efficiency and conservation strategy

- use market strategy to encourage conservation and efficiency

\begin{tabular}{l|l} 
Market Driven & "The Environmentallsts' drumbeat - BUTI - this means a \\
regulatory price-setting function."
\end{tabular}

? Rely primarily on market mechanisms which reflect true cost to determine which energy costs are used (interfuel/intersupply competition)

"This had potential with some work on the words"

- Create incentives of some kind which will compensate for factors of environmental and/or social cost that are not yet incorporated in the market - internalize these incentives at the point of the decisionmaker |"There was a potential opportunity for the group to" come together on an emissions tax."

? Consumption tax |"needed real negotiation"

? Import tax |"ADD encourage indigenous sources/ social benefits of local spending"

- Information to help the market work better

? Fee-bate | would take lots of getting used to"

- Make utilities' least cost choice also be their most profitable choice all sources bidding, with fair transmission access, and amendment to PUCA to provide level playing field

- Be neutral towards transportation modes, so they each pay their own way

\section{Efficiencies}

- After penalizing polluter, make the market mechanism work

"I don't remember this - better to say, 'Create disincentives for pollution."'

? Least-cost planning

? DOE R\&D should emphasize efficiencies and renewable resources both in supply and demand

- All source bidding as a means to supply has to go with transmission access 
- Improve gasoline inefficiencies using "fe日-bates" and CAFE standards
"There was lots of talk about this, but no real agreement."

\section{Envirenmental}

Enhance environmental quality by: "for the three options below, there was real opposition in the group. They would have taken serious negotiation, but were promising"

? Accelerating development of CNG and electric vehicles, mass transits, reducing fuels available to other energy sources

? Accelerating depreciation for replacements to obsolete facilities

? Self-financing federally chartered corporation for nuclear waste (apart from DOE)

\section{Supply}

- Provide security in the supply pattern

? Create separate reserve for refined oil products

"there was a lack of understanding on the benefit of this option - 'what is it buying you?' With time people could have gotten an explanation"

? Promote nuclear and clean coal technologies

- Maximize US oil and gas from existing fields

? Economic incentives for

"We were diverted from a real discussion of natural gas by the nuclear representative. There was no understanding that we're selling gas at spot-market prices that are lower than our production/lifting costs." proving new resources

- Public participation early in siting process to improve its efficiency

- Establish site banks for future energy facilities

- R\&D for clean coal technologies, advanced oil and gas exploration, electric

- Need to accentuate long-term contracts in gas industry - need to move from spot markets

? Licensing process for nuclear plants needs to be streamlined, combining construction and operating permits

- Gas contracts must be based on mutuality of obligation 
Appendix C - Annotated

Negotiation Table Reports

\section{Verbatim Report of Negotiation Table \#2 to Plenary Session NECE, May 22, 1990 6:00 pm}

This group comprised members of administration and planning in the electric, coal, oil, natural gas and nuclear industries; a representative of the financial community; legal counsels to consumer, environmental, and business interests; and a US Governor and other members of the government.

(Optlons marked "NEW" were created by the group during the negotiatlon session)

NEW Prioritize programs at National Labs to be consistent with the National Energy Strategy, and significantly increase R\&D funds to universities

NEW Develop a strategy for an effective mass-transit system, with an appropriate funding mechanism

NEW Investigate alternative fuels for fleets in urban areas

Preserve nuclear as an option for baseload electricity

Require integrated resource planning for electric utility companies

- Provide incentives to utilities for conservation and load-management "Conservation was the programs common ground."

- Extend funding for R\&D and for commercial demonstration and deployment of CCTs

- Use US markets to encourage passage of comparable environmental standards in foreign countries

- Improve international industrial competitiveness through policies and programs that take into consideration economic competitiveness, the environment, and energy supplies

- Require least-cost planning for all vehicle transportation usage 


\section{Appendix C - Annotated Negotiation Table Reports}

NeW Create incentives for secondary and tertiary development of oll and gas fields

- Create a separate reserve for refined oll products

NEW Streamline and stabilize the regulatory environment

NEW Provide access to federally-regulated lands for coal, oil, and gas exploration, development, and production, consistent with environmental regulations 


\title{
Verbatim Report of Negotlation Table \#3 to Plenary Session
} NECE, May 22, $1990,6: 00 \mathrm{pm}$

\begin{abstract}
Members of this group of negotiators included: representatives of the transportation sector; administrators from both smaller independent and larger utility, coal, and oil companies; a US Governor and other government representatives; advocates for environmental issues; and industrial consumers.
\end{abstract}

"These represent trades on two levels. All of the policy options under each heading represent a traded agreement on that toplo; in addition, there was an overall trade that the O\&G trades would not be accepted unless the Electriolty trades were, etc."

\section{ELECTRICITY}

Utility Regulatory Reform

- Provide incentives to utilities for conservation and load management programs

- Develop procedures and incentives for utilities to provide transmission access I"A PRIORITY. I would add to that 'NEW Level Playing Fleld for Renewables"'

- De-couple utility profits from kilowatt hours

- Amend PUCA to facilitate competition in wholesale service with level playing field for registered holding companies and recognition for consumer protection

- Reestablish federal preemption over wholesale transactions

- Revise FERC regulations and state law so that decisions made by a commission are binding on future commissions except for just cause shown

- Preserve all fuels as options

- Stable regulatory process

\footnotetext{
"People were willing to agree and negotiate the "standard" arguments speclito to their Industry, but there was an unwillingness to set a goal for the future stablility and securlty of energy supply and need for this country and then make the hard decisions to get us there."

"The wrap-up was ineffective - too many issues with no value order or key items isolated - we did net reach substantive agreement on a final, all encompassing energy policy - but probably identlfied some good ideas."

"The issues are too complex - what appears to be consensus under pressure becomes disagreement wherl we have time to contemplate."

"In order to produce something, we got into generalities. "The devil is in the detalls" - no chance to get there, in that context."
} 


\section{OIL AND GAS}

- Set OCS environmental regulation on an area-specific basis

- Maximize US oll and gas output from existing flelds, and bar any development of environmentally sensitive lands (need to define)

"This partloular optlon caused some problems in the group that actually served as a breakthrough of sorts. One partioipant was particularly opposed to the wording of "bar any development," and spoke for at least 15 minutes about why it was a bad ldea.

Eventually he was out off. But the group got baok to the toplo and decided that the real problem was the term "environmentally sensitive" and resolved that that term would have to be better defined. They turned it into a problem of language rather than a problem in principle."
"We didn't agree to this, really. We said no to spoolfios, but in general content it was a workablo idea."

- Predictable, long-term rules about availability of federal lands

- Stabilize regulatory environment for oil and gas exploration

- Economic incentives for proving new reserves

- Set ANWR environmental regulation on an area-specific basis

- Share existing royalties on production with state and local governments

- Fund R\&D in advanced exploration methods

- Provide tax incentives for domestic gas and oll exploration, development, and recovery

- Provide tax incentives for enhanced recovery on existing flelds

- Increase federal gas and diesel fuel tax by $\$ .10$ for 10 years (\$ will support transportation infrastructure, accommodate low income/rural citizens)

- Increase CAFE standards

- Tighten appliance and building efficiency standards 


\section{NATIONAL SECURITY}

- Standby authority relative to SPR

- Ensure future electrical supply

- Rationalize liability exposure

- Increase overall level of federal R\&D funding in energy (prioritize according to cost/benefit analysis)

- Ensure that cost effectiveness and international competitiveness be considered in any major federal action

- US takes leadership role in fashloning international standards for energy development and environmental protection.....

- US does not take unilateral action which would have long-term competitive disadvantage

- International emergency planning

- Increase R\&D in energy efficiency

- Increase technology transfer, commercialization, and demonstration

CLEAN COAL TECHNOLOGIES |"Our major resource. Should

- Expedite environmental permitting process for CCTs

- Extend Clean Air Act compliance time via waivers for CCTs

- Extend current R\&D/increase funding for commercial demonstration and deployment of CCTs

- Actions of gloival climate change should be integrated on an international basis

- Encourage and initiate CCT on international basis. Where applicable promote renewable energy/least cost planning

- International research efforts on global climate change should integrate both scientific and economic impact 


\section{NUCLEAR}

- Preserve nuclear as an option for baseload electricity

- Commit to development of terms under which stream-lined licensing may occur

- Investment to improve power plant design

- Investment to solve waste problem

PUBLIC EDUCATION

- Citizen education on energy economics 


\section{Verbatim Report of Negotlation Table \#4 to Plenary Session NECE, May 22, 1990 6:00 pm}

Members of this negotiation table included: consultants; representatives of environmental and conservation groups; the oll, electric, nuclear, coal, and natural gas industries; legal counsel to and an administrator for industrial consumers; public energy organizations; and a representative of the transportation sector.

\section{GENERALPRINCIPLES}

- Encourage energy efflclency

- Gain with least pain (minimize loss of mobility/ convenience)

- Rellable cost efficient supply

- Minimize regulation - promotes a more open marketplace consistent with environmental and long term perspective

\begin{tabular}{|l} 
"We agreed to \\
more than \\
showed up on the \\
aoetates, Our \\
faollitator ran \\
out of time to \\
reoord everything, \\
For example, we \\
worked out an \\
approaoh to the \\
problem of global \\
warming that \\
doesn't show up \\
here, whioh \\
resembles Table \\
3's statements on \\
thls subjeot."
\end{tabular}

- Seek global solutions (broader than US) which enhances US economic competitiveness, but also bullds international/global cooperation

- Promote equity regarding:

- Rural/urban

- Regional

- Income levels

- Sectors

- Inform consumers so that they are active players in energy strategy

- Consider cost/benefit trades in all policies

- Encourage R\&D and technology transfer

- Policy must reduce vulnerability

- Minimize environmental impacts

- Least cost planning across sectors

- Incentives rather than Command \& Control (as much as possible)

"Wo were gelling newhere - let's put up an easy one llrst - so I dld, but wont down In llames. Faclltrator was way, way oll - I walked out, as did others. Faclilitators had existing alliances with onvironmontallsts. The Industrlal complex woro llvid. No irading: simply votling (down) oach existing packago. Silli, wo dld a better job than most, but It was Monopoly money - no real stakes." 
- Integrated policy whloh Includes Energy, Environment, Economy, Natlonal Security

- Implementation prinolples

- No net drain on budget

- Tax polloy should not make energy polloy

\section{Utillity Package}

- Standardize nuclear energy plant designs

- Increase R\&D on advanced nuclear energy plant designs

- Establish a "site bank" for future utility ne日ds

- Tle new nuclear development to siting a permanent spent-fuel repository

The wording In item 15Q was ohanged to read: "Continue and faollitate sate on-site spent fuel storage, aooelerato siling and con truotion of a permanent repository and a oentrallzed federally monltored retrievable storage faollity." Thls oorreoted wording wau reoorded at the other tables.

- Integrate construction and operating licensing Into one-step process

\author{
To the option as stated "Integrate oonstruction \\ and operating lloensing into a oine-step prooess" \\ should bo added the phrase "with quallty audits \\ by the NRO while the plant ls being bullt."
}

- Develop comprehensive consensus-based public participation process

- Require least-cost planning for gas and utllity companles

- Increase use of renewable in federal facillties

- Provide financial incentives to utilities for conservation and load management programs

- Develop procedures and incentives for utilities to provide transmission access

- Obligation to serve requires utility decisions on supply and delivery options

- Assure a stable and predictable regulatory process over the long term

- Reform utility regulations to make the least cost plan the utllity's most profitable plan 


\section{Iransportatlon Package}

- Eliminate disincentives to mass transit

- Encourage use of electrio vehiale fleots In urban areas

- Now "Efflclent Auto" packago:

a) $40 \mathrm{mpg}$ CAFE standard for cars

$35 \mathrm{mpg}$ CAFE standard for light truoks

(by year 2000 through percentage increase by manufacturer)

b) $\$ .50 /$ gallon (In 1990 dollars) gas tax phased in over 5 years.

Dedicated to transportation (Including mass transit)

c) Guzzler tax/slpper rebate; +1- $200 \mathrm{mpg}$ slope

d) Revise CAFE standards to consider vehicle capacity and use

Oll Aareements There was surprisingly littlo foous on oll, espeolally the domestlo oll industry."

- Minimize drilling and Import restrictions

- Mitigate vulnerabllity, but accept dependency

- No import fee

- Fund R\&D in advanced exploration methods

- Set OCS environmental regulation on an area-specific basis

- Stabilize regulatory environment for oll and gas exploration

- Predictable, long-term rules about avallabllity of federal lands

- Royalty production holldays on marginally productive stripper wells

\section{II'd say the real neods of the gas guys}

- Streamline licensing process for natural gas pipellne construction

- Adopt rate design reforms that encourage efficient use of pipeline capacity and storage

- FERC encourage contracts with mutuality of obligation

- Encourage FERC to approve contracts which reflect the cost of maintalning adequate gas supply

"Entirety of oll
paokage put together
In the last llve minutes
of prooess. The
vlabllity of the
"negotlated paokage"
has to be suspeot."

has to be suspeot."
"Outside the context of a oarbon tax, for which there was no ooal support, there was surprisingly IItt/o environmental support for returning the domestio natural gas industry to eoonomio viability. It was as If gas would be avallable any timo in any amount simply for the asking." 


\section{Verbatim Report of Negotlation Table \#5 to Plenary Session NECE, May 22, $1990 \quad 6: 00 \mathrm{pm}$}

This negotiation group included members of the academic and financial communities; power research and planning organizations; environmentalists and conservationists; representatives of industrial and consumer interests; and administrators from electric and natural gas companies.

\section{ENERGY USE}

- Increase DOE R\&D and use efficiencies budget

- Tighten appllance, bullding motor and light efficiency standards and expand use of mandatory labels

- Develop and implement mass transit system

- Provide adequate financial incentives for demand-side Initiatives

- Create efficient and effective incentives for purchase and use of renewable energy equipment

- Encourage the development of predictable, long-term rules about avallability of federal lands - the rules developed in cooperation with environmental, Industry and state representatives

- Integrated resource planning: ensure demand, supply, and renewables are equally considered in energy planning

- Continue US support for international energy contingency planning in the IEA and other international organizations

- Preserve nuclear energy as an option for baseload electricity by finding $R \& D$ for advanced designs

\footnotetext{
"The most important aspect of the whole session was one of eduoation and pre/udice-bashing - as Tina Hobson sald at dliner, "It was nice to finally sit down and talk to the stakeholders and not thelr lobbylsts." I tolt that this session was a dellnite Irst step toward meaninglul talks for exaclly that reason - people were actually talking to one another. The nuclear representatlve was blown away by the tact that the environmentalists were actually entertaining the thought of nuclear energy at all, never mind as an option for baseload.

"This session gave people a chance to educate one another as to what thelt ceal conoerns are. The real dynamlo of the negollation was in the language - the group was constantly pressing for olarlty, and poople got air-time to explain what they meant by terms like 'streamline' or 'oreate Incentlves.' When the natural gas person explained what they have to go through with lloensing, elo, people were very sympathetle, and understood a litlle better what that group was really trying to gain out of their negotlations. Onco people heard the reality of the sltuation, they set to reflining the language of the polloy - somellmes making more general, sometimes more speclilo - to oet to scimething they felt would accommodate everyone fairly and acoount for 'what was necessary. '"
} 
- Explore ways to stop International nuclear processing

- Commerclalize advanced gas turbines for stationary power

- Streamline construction and operating llcensing of necessary energy facilities by providing sufficient resources to expedite thorough environmental and other permitting

- Have FERC develop a gas inventory charge that encourages marketable long-term gas supplies

- Actions on global climate change should be integrated on an International basis

\section{ENERGY SUPPLY}

- Promote International safety and environmental standards for all sources of energy supply

- Recognize and assess economic and environmental actions with negative implications on US competitiveness

- Allow stationary source emission trading (including trading with end use)

- Streamline certification for gas transmission pipelines by providing sufficient resources to expedite through environmental and other permitting

"The group I was in passed a consensus (we thought) to the effeot that we should stop exporting our refinery capacity to foreign reglons where we lost seourity of supply, oconomio beneflis, and where host countries did not have the striot environmental regulations we have in the USA. Pollution knows no national boundaries."

- Address vulnerability question:

Consider the following (We as a group do not recommend or endorse the following)

- Avallable products

- Transportation

- Gasoline tax

- Demonstrate synthetic fuel products on commercial to set cap 


\section{IOREDUCE FUEL CONSUMPTION}

- Adopt stringent CAFE standards

- Substantially increase motor vehicle fuel taxes (increased taxes would be applied to mass transit)

- Direct incentives for purchasing energy efficient cars

- Continue and facilitate safe, on-site spent-fuel storage; accelerate siting and construction of a permanent repository and a centralized federally monitored retrievable storage facility. Explore a self-financing independent federally-chartered corporation to manage storage of the nation's commercial nuclear waste.

- Allow Construction Work in Progress (CWIP) in the rate base

- Fund R\&D and commercialization for renewables/efficient energy technologies

- Increase R\&D funding in energy efficiency

- Increase technology transfer, commercialization, and demonstration

- Expand substantial!y the fraction of civilian R\&D budgets of DOE - EPRJ \& GPI devoted to conservation and renewables, emphasize applied research including social sciences 


\section{Verbatim Report of Negotiation Table \#6 to Plenary Session NECE, May 22, 1990 6:00 pm}

Among members of this negotiation table were: industrial consumer groups; a member of the transportation industry; members of the nuclear energy industry, electrical utilities, and of enorgy planners and providers; an academic; energy research organizations; an attorney; and a member of the financial community.

\section{Utility Policies}

- Require least-cost planning for gas and utility combanies

- Reform utility regulations to make least-cost plan the utility's most profitable plan

- Provide financial incentives to utilities for conservation and load management programs

- Make electric and gas utility regulation process predictable

- Tighten appliance and building efficiency standards

- Combine home energy ratings with energy efficiency reward on mortgage

- Timely and predictable licenses for power generation facilities

- Deveiop procedures and incentives for utilities to provide transmission access

\section{Energy Supply Policies}

- Preserve aلl fuels as options (including renewables)

- Mitigate vulnerability (but accept dependency)

- Create a separate SPR reserve for refined oil products

- Ensure adequate refining capacity and import receiving facilities 
- Provide tax incentives for domestic oll and gas reserves [exploration, development, recovery]

- Set OCS environmental regulations on an area-specific basis

- Standardize nuclear energy plant design

- Tie new nuclear development to nuclear waste:

- Safe on-site storage

- Accelerate permanent repository

- MRS

"The wording on this is WRONG. Should read: "Continue to facilitate safo, on-site spent-fuel storago; accelerate siting and construction of a permanent repository and a centrallzed federally monitored retrievable storage facllity. "w

\section{Environmental/Transportation}

- Increase CAFE standards to $35-40 \mathrm{mpg}$ by 2000 (so long as there is no gas tax included)

- Increase guzzler tax/initiate sipper rebate

- Reduce $\mathrm{SO}_{2}$ emissions to 10-12 millions/year by 2005

- Increase funds for mass transit

\section{Besearch \& Development}

- Focus R\&D on advanced nuclear plant design and fusion energy with designs that are appropriate for competing in world energy markets
"The wording we agreed to on this is: '- Increase R\&D for advanced nuclear plant design and fusion energy and renewables. Foous on energy designs that are appropriate for competing in world energy markets'"

- Extend current R\&D funding level/increase funding for commercial demonstration and deployment of Clean Coal Technologies

- Increase R\&D funding, and demonstration for renewables, emphasizing long-run best buys

- Increase R\&D funding on technology transfer and efficiency 


\section{Consumers}

- Provide conservation subsidies for vulnerable groups - elderly, handicapped, and low income

- Citizen education on energy economics

- US takes leadership role in fashioning international standards for energy development and use and environmental protection with monitoring and enforcement mechanisms 


\section{Verbatim Report of Negotlation Table \#7 to Plenary Session NECE, May 22, 1990 6:00 pm}

Members of the group include energy education and energy strategy organizations; attorneys and advisors to energy concerns; a consumer advocate; a member of the academic community; representatives of the coal, nuclear, natural gas, public utility, and transportation sectors; and environmental and conservation groups.

ENERGY CONSERVATION,
EFFICIENCY, AND
REGULATORY REFORM
$=$ the cornerstone of $\quad \begin{aligned} & \text { This line was } \\ & \text { really a } \\ & \text { phllosophical } \\ & \text { starting-point } \\ & \text { tor the group } \\ & - \text { nota } \\ & \text { pollicy/topio" }\end{aligned}$
national energy strategy

\author{
"At no time did the group discuss making this \\ statement, lot alone agreo to it. \\ I would llke to veto. Ibolleve that every \\ Indigenous energy resourco has an Important rolo \\ In the nation's energy mix. . . \\ Also, the group would not have agreed to \\ regulatory relorm as part of the cornerstone. We \\ held very different viows of the reform needed. . . \\ we never agreod to a common meaning although \\ there was oonsiderable discussion."
}

"The group did not endorse all regulatory reform,

but only the four speciflo reforms specifled."

- Least cost planning for new and for

"LCP seoms to be a labol chosen by consumerl environmental groups - not sure if the entire group understood what it meant" operation of existing utilities

"After this line there is an implied BUT, and the next two lines are

contingent options. This forms a sort of trade by the group"

- Consider externalities

- Consider uncertainty

\section{"contingency adjustments as provision by industrialists"}

The following three options are really examples of the above ideas, they support LCP in more concrele ways"

- Permit utilities to earn a rate of return on investments in conservation. No penalties for success.

- Policies to encourage integration of electricity transmission systems

- Expedite/streamline licensing for natural gas pipeline construction

\footnotetext{
"I found the representation strange - electricity issues were being put forward by environinentalists and consumer advocates/the representalive for oll (as he admitted himself) really wasn't a representalive for oll, and the representatives for coal and electriclty didn't say much of anything. The public interest and environmental representallves did the most "reaching" (though that doesn't mean that the rest of the group did a lot of learning). All of the Industrlalists seemed to really be on the delensive agalnst them; saying "Tell us what you want - we know we have to agree anyhow even though we have virtually no leeway to make adjustments"

The environmental person ended up being a real lce-breaker. He put things into a perspective, and used a language that got everyone else talking to each other. He got them to think differently about how everything was connected and what the purpose of the negotiation was"
} 


\section{International coeperation on energy and envirenment}

- US lead on International standards for | "but not holp others - just show energy development and use;

I" Right here we find another Impllad BUT; the continuation of this is a contingenoy olause"

No US action which would have long-term competitive disadvantage

\section{Competitiveness and fiscal soundness}

- Maximize the use of domestic resources

$$
\begin{aligned}
& \text { "oll" should } \\
& \text { really be } \\
& \text { inoluded here" }
\end{aligned}
$$

"I think that the next three policy options really support the 'International cooperation' section. II I were writing this thematioally, I would oonneot them together"

- Encourage environmental standards in foreign countries, and promote development of energy technologies to achieve this

- Improve international industrial competitiveness through policies and programs that take into consideration economic competitiveness, the environment, and energy supplies

- Ensure that cost-effectiveness and international competitiveness be considered in any major federal action

\section{Natural Gas}

- Improve the economics of natural gas exploration, production and development

(NOTE: 2 sub-groups of group 7 attempted to include options for oil exploration and recovery, but time and lack of advocacy made this difficult)

"It is not included in this report that Table 7 agreed that R\&D should be increased for every energy resource - coal, oil, gas, renewables, conservation. There was a good bit of disoussion on this."

"This report does not include our agreement on decoupling utility profits from the impact on sales of conservation programs." 
- Preserve nuclear as an option for baseload electricity
"This is the point of agreement, with the implied BUT after it, and the following 3 loplos are the contingenoy requirements to agreement on this toplo. They are the only way that this toplo ls going to bo ok'd"

- Address unresolved issue of permanent spent-fuel repository

- Standardize nuclear plant design, and require that completed designs be approved

"I think that this is really two very different toplos, and would split it into two separate bullots" before construction is approved

- There should be established a balanced R\&D effort among energy types, including renewables and efficiency options

Group VII speolfically agreed to the polloy on waste worded as follows: "Continue and facilitate safe, on-site spent-fuel storage; accelerate siting and construotion of a permanent repository and/or a centralized monitored retriovable storage facllitj: " One of the lessons learned for the future is to have the particlpants sign off on written statements rather than leaving agreoments to the interpretation of a moderator.

"This does not refleot the speoiflo words agreed to on the nuolear subjeot. If should read:

-. Preserve nuclear as an option for baseload olootriolty ang part of. the eneray mix

- Anv naw olants should be of standardized design appreved by the NRC

-- Complete designs sheuld be submitted betore construotion ls approved

-- Address unresolved lssue of permanent spent-fuel repository

-. There should bo a balanood R\&D offort among energy ootlens inoluding renewables and effiolenoy options

\section{National Securlty and Imported Oil Vulnerability}

"I don't know if National Seourity and
Imported Oll are the same thing and
should be connected so olosely"

"I think this got onto the transparenoy simply because of constralnte in time - pouple were getting tired and the plenary session was starting by the time they got to It. In the real world I am sure that people would not have agreed to it."

- Increase CAFE standards

- Require least-cost planning for all transportation, which will lead to increased mass transit usage

- Lease oll and/or oll reserves as alternatives to SPR purchases

- Create separate reserve for refined oil

- Encourage increased SPRs in IEA countries

"I don't think that there was a full understanding of what a SPA is, or who the IEA is. There were really iwo people in the group who understood and debated, and the rest of the group agreed to their basic ideas without

tully understanding." 


\section{Verbatim Report of Negotlation Table \#8 to Plenary Session} NECE, May 22, 1990 6:00 pm

Participants of this negotiation session included: a representative of government; an industrial consumer administrator; environmental legal counsel; representatives of energy delivery and energy strategy organizations; a natural gas company; a representative of environmental and conservation concerns; and a member of the financial community.

- Preserve all energy options that lead toward an environmentally safe and economically viable energy policy

- Encourage market-based regulation in generation of electricity

- Decouple profits from sales; reward efficiency investments (Incentive regulation)

- Amend to PUCA to encourage competition in wholesale service

- Transmission access

(ripe for developing detalls through this process) "This parenthetical phrase applles to all of the bullets under "enoourage."

- Mitigate vulnerabllity but accept dependency on oll imports

- Investigate ways to do this

- Differentiate between vulnerability and dependency

Would add - Need to define what problem is

- No "percentage trigger" on imports"

- Open federally regulated lands WHEN:

- Economic conservation/efficiency steps taken first

- Existing supplies used efficiently

- Not wilderness lands/national parks

l"Add - No federal planning"

"Add 'by consumers, producers, and suppliers ${ }^{\text {n }}$

- Streamline nuclear licensing and standardize design of nuclear plants

- Maintain public participation including development of standards

- Develop acceptable designs (R\&D)

- Develop criteria to meet public acceptability

- Nuclear energy: If safe and environmental and cost effective, should be an option 
- Increase federal renewable R\&D

- Especially long term ( $>10$ years)

- Should be at least as much as is devoted to nuclear

|"Add - Publio seotor use and purohase"

- Increase federal energy efflciency R\&D

- Redirect funds in existing Clean Coal Technology program to focus on energy efflciency and $\mathrm{CO}_{2}$ emlssions

- Includes basic research and pilot plans

- Includes reconstruction of Stanley Steamer

- Consumption of fuels by autos needs to be reduced

- Increase CAFE stanciards

- Guzzler fee/sipper rebate (revenue neutral)

- Gas tax partial rebate to states and to oil and gas industry 


\section{APPENDIX D: OPTIONS MATRIX: TABLE BY TABLE}

This matrix records:

1) polloy options endorsed by each table;

2) ("NEW") policy options invented by individual tables; and

3) policy options endorsed in caucus that were not endorsed by any negotiating table.

The organization of the matrix is explained in a legend on its final page. Abbrevlations used within it are explained in a running footnote. 
Molor Vohlolo Uanga

CAFE slandardy: Incioase

1035.40 mpg by 2000

as lorig as thore 19 no gas lax lincludud

$1040.45 \mathrm{mpg}$

to mpe plus porountago of manulaturor

lovigo lo consldor vohlolo oaprally and use

Fodarill gneolline and diegol fual lax:

Incroaus by $\$ 1.00 \cdot 2.00 /$ gallon

$\$ 1 /$ gallon lax

No lnoroaso

Incronso by $50 \mathrm{~d} / \mathrm{gallon}$ ovar llve youlrs

Inctoaso by $10 \mathrm{c}$ lor 10 yours (\$ will support if ansportation

Inlrastmolure, acoominodale low Income/rural oillzenss

Incroase wilth partlal rabate to oll and gens licluslry

Mass Translt: Improve

Incruase toderail turiding lavola

Provido tax and'or other Inconilvas lor busliogs mases tranoil prograrns

Ellininate dialncontlvos

Devolop a siralegy lor an ollocilivo system,

with an appropriato lunding mochanlsm

lundod by ofl limpon loo and gas lax

Bequlre uso ol olecirlo vohiclo fleols in uibar aroas

Encourage alootrlo vehiclo llouts in urban ar aas

Acoolarale devalopmont of CNG and oleatrio vohiclos, masss Wansita,

roduclng fuels availablo to other onergy sources

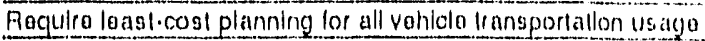

Invesilgato alternatlvo luels for floots in urban areas

Gas guzzlor lax

Gas alpper rabato

Bevenue noullal guzzlerisleper lax robato wilh +1.3200 inpos slopa

Dlrect inconilves lor purchasing enargy affledent cars

importod Oll

No Import souree resificilons

Milnimlze drilling and lmpont restictions

NoImporloo

Limil limports 10 gome percentage of lotal comes sic production

Miligalo vulnerabilly (but aocept dependency)

differontialo botwo on vulrerability and dopendence

Stralogle Potroloum Rosorvo (SPR] (Nallonal Socurlly)

L.ease oll and/or oll resorvos as allornallvos $10 \mathrm{SPH}$ purchases

Croalo a separate resorva tor rolined oll produols

LIndi SPA pelroloum salos to quallited domostla rallinars

Encourago Increased SPPa In other IEA countrlos

Provldo slandby authorliy lor SPA roloaso

Energy Allocillon Polloy: Crisls Conilngoncy Planning

Do nothing but allow prlce shocks lo lake caro of encergy supply allociation

Allow market forces la take oare of onorgy supply allocation

Develop plang, based on Inlernallonal energy cooporation, lo assuro coordlnaled energy proparedness

Devolop coordinaled stalo and lod oalastrophilo shorlaige conting ancy plan

Foclerally Regulated oll and Cas Explorallon on Fodoral Holdings

Sut OCS unvlionmental regulatlon on an aroa.spocllio basls

Sot ANWF environmental regulatlon on an area. spoolllo banla

Open lederally regulaled lands under axlellno condilions

\begin{tabular}{|c|c|c|c|c|c|c|c|c|}
1 & 2 & 3 & 1 & 5 & 6 & 7 & 8 & $N E W$ \\
\hline
\end{tabular}

$\cdot$

$\therefore \quad \therefore \quad$ M

Fodorally Rogulalad oll and ong, cont.

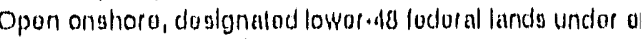
onvironmontal rulog

Maxlinitio U.S. oll and gan oulput lom axls ling lialda and bar any new dovalopmonte of environmontal

Hoyally produallon holddays on marginailly produotivo atelp:

Pradiolablo, long. iorm rulas aboul avallabilly of lodoral lai Sharo oxtating royalllus on productlon with stalo and looal

Stabilizo logulalory environment for oll and gas oxplorallo

Economla Inoontlves Ior proving now rosurvos

Frovidu accoss 10 lodurally.rogulalod lands lor oon, oll, a exploration, dovolopmian, and production, conglotont onvironmental rogulatlons

Open loderally rogulatad lands (NOT wildornoso landiona WHEN: Consarvalloh and olllolonoy monsuruo havo: AND Existing suppilos aro usod ufflclantly

Explormilon and Dovolopmont of Naw Domosllo oll an

Provida lnvestrmont lax arodil for uxploralion, devolopman Fund Be In advanced oxplonatlon molhodo

Provldo lax lincontivog lor domestio oll and gas oxplerallor andrecoy

onhanued recovory on oxis wing

Inconlives lor aocondaty and torllary dovolopmont ol oll a

Nalural Gas Transmleslon and Uso

Stroamilno lloonsing proooss for natural gas plpollno cona

Adopt rala dosign rotorms that ancourago offlodont uso of and slor ago

Enoourago long. erem contracls and mutually of obligatlon

Enoourago FEAC to approvo contracle whiloh rollocl tho o adoquata gas supply

Improvo tho aconomles of nalural gas oxploralion produc dovolopment

Provide a prlco lor nallural gas which will oxoood the ropla now rogorves

Assurad Elocirlclly Supply

Provtdo opon transmlsglon accoss

Falr trangmisson acooss

Slte banks for luturo oluctrio supply noodo (transmisgion c hogulatory process: slroamilina

$$
\text { Stabllizo }
$$

Slablo logis/allye and rogulalory procoss

Assuro a slabla and predictablo rogulatory proonss over it Prosarvo all luols as optlons

Obligation lo sorvo rocuirus utillty doclsons on supply ant Commerciallzo advanood gas furblnos lor stallonary powi Uillily Rogulalory Rolorm

Provido linanolal Inooriltuos to uillitlog for contuorvallon ane managomant programs

Minir.ilzo regulatlons, promolo opon markotplaco

Allew CWIP In tha ralo baso

Struarnline lloonging and pormltting

Allow environmontal miligatlon costs to ba onpitallzod

Deregulatlon of pubile and privalu utllling

Roguleo a rogulation rolorm lo make the loast cout plan it prollabla plan

Fucpulro loast cost planing for oach utllly's oloctlo suppl

Poplace ended-constiuction prudonco roviows with rollin roviows or parlodic CWIP rovlows

Aoquire all-sourco bldding Indudling axternalltios 


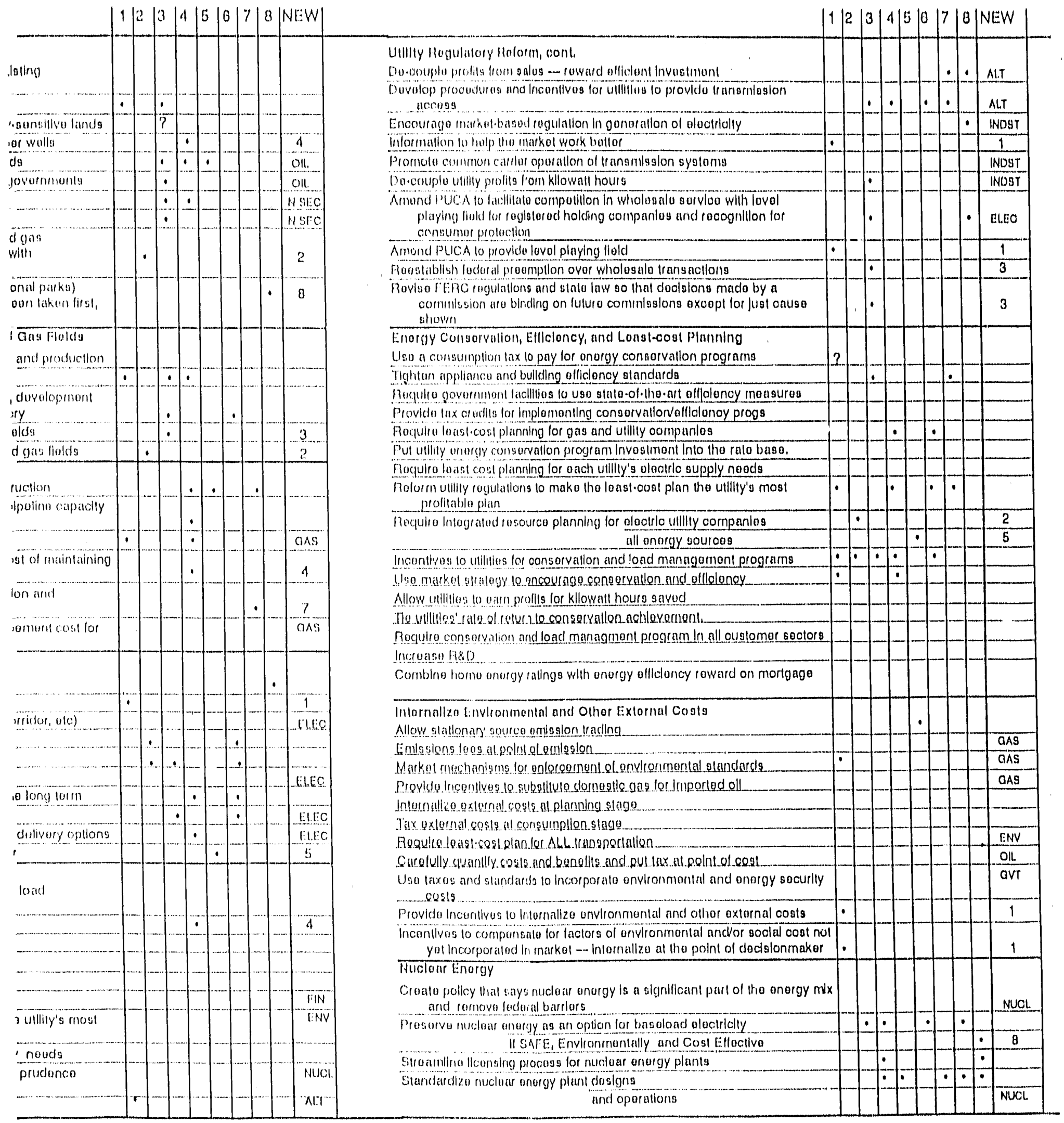

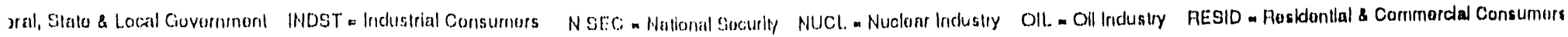


Nuoloar Enorgy, cont.

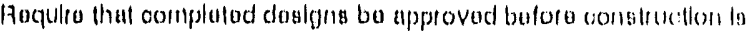
ripprovad

Incranga R\&D on advanood nudear unargy planl dasignas and fusion onargy

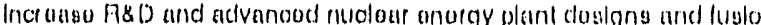
unorgy with dostgns that aro approprialo lor compoting in the world unargy markat

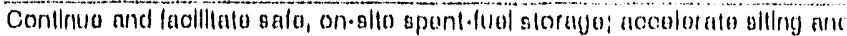
construation of a parmanont ropastory and a contralizud fodoral

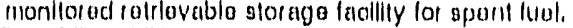

Eatabliah a sell. llnanoing, Indapendant tedarally charlored corporallon to manago atorago of the nallon's commordal nucloar wisto

Standard plant doslon and ano.stop llaonsing

Addross unrosolved lesue of nuclear wasle

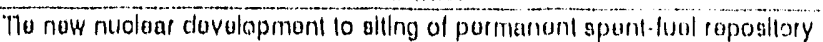

Powor Plant Approval and Construclion

Lirnl scope of prudunco ruviows

Allow Construction Work In Progross (CWIP) In the lalo bast

Integralo Into a ono stap procoss: slling and parmitting

construotlon and oporating Ileansing

Feplaco prudonoe laviows wlih CWIP lovlowg

Egtabligh a sollo bark" lor futura utllity noeds

Acoulorulo claproclatlon of replacoments to obsolete facilltios

Allow Lllor of - laollity porriliting

Dovulop comprohensive consunsus -bissod publie parlloipation procoss including devolopment of elandards

Dovelop criturla lo meel public accoplability

Publlo partlolpatlon process to expodile environmontal, logal, and cogulatton approval procoss

Ronawabla Supply Sourcos

Incruase R\&D funding lor ronowablog

Allow non.ullity producars to compelo

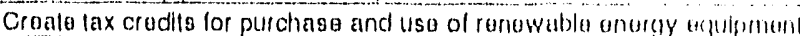

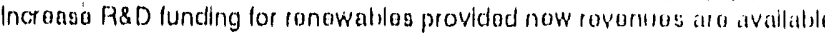
from some lax

Requiro all sourco bidding,

Including anvironmental uxlurnatitios

Incruaso R\&D and domonstratlon, omphaslzing long.run busi buys

Incroaso uso in fodoral racilltes

Domonstrato bloluols as lool lor sustainable larming and forostry

Straarillna parmitting lor ranowables (Including hydro pump storago)

Cloan Coal Tochnologlos (CCTs)

Expodite onvironmental permilling procoess for C.CT's

Extund Cloan Alr Act compllance lime Vla walvers lor CCTs

Exlend currom $\mathrm{A} \& \mathrm{O}$ funding lovol/norease funding for commutidal domonstrallon arid daploymont of CCTs

Fodirool furids In exlsting CCT prograrn to locus or unigrgy utlictericy and CO2 ernlssiona (Includea baslo researoh and pllot plantsi)

Alr Toxles and Other Alr Emlsslons Irom Stallonary Sourcos

Fequlira BACT lor expanded doflnillon of sources

$(0,0,>5$ tons/yr single; $>15$ ions/yr multiplo

Consumption lax on carbon-emililng luels

Emissian funds to imporiad fuals

Emvssion roduction 10.12 uillity/industry

Legislation to ancourage and fund CCTs

Foduce SO2 10.12.millons/yoar by 2005

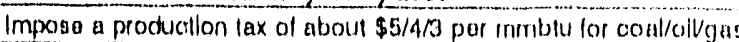

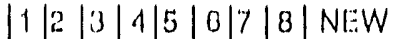

$7^{2} \cdot 7^{8}$

Consumor Wollaro and Educullon

Provldo consorvallon mibaldlos for oldarly, hanclioappod, groups

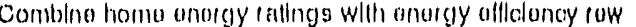

Eolablish folooallon/f entraining fundling and programo for Indusliy workus

Provida allootlva inlormalion on unorgy olliolondas on la

Provldo Inlormation and oclucallon to consumors on onor allornalves and mothods

Citlzen aduarition on unorgy aconomiles

Compollivonosy and Fiseal Soundnogs

Incroaso ovorall lovol ol loderal A8D lundling In onergy

Maxlmizo the use of domastla rasourous

Uso US markots 10 encourage the passago of onvironmo Ioreign oountiles

Put mobility as pilmary usa prionlly tor llquid luols

Expand R\&D lax crodils

Balanco lodoral budgel; control inllallon; Improva savings aaplail Invostmont

Ausoss and revlso laws which nogativoly Impanot Intornall compotitivenass of US products

Improvo Intornallonal industrinl compotitivonoss through programs that lake Into consldoration voonomlo com environment, and onergy supplles.

Ensura that cost.olloctivonoss and international compolt corisidurod In any ma|or fodoral aotion

Incroaso ovorall lovol of ledoral R\&D lunding ln unergy according to oost toonoflt analysis

Enorgy R\&D/Tochnology Translor *

Croalo lax orodits for purchaso and use of ronownble on

Establishud balanoud allocation of $\mathrm{AQC}$ (D) among onorgy is renowables and offluloncy

Fund $\mathrm{R} \& \mathrm{O}$ and commeralalization for tonowabloticlont lachnologless

Provldo luchnology 10 tho world to survo: global socurity, onvironnant

Invostigale polontho for exlsting DOD tochnology ir anslo

Increaso AeD funding in onoray offialoncy

Incrotseg loohnology tranglor. Roduce and raallocate $\mathrm{R} \& \mathrm{D}$ lunds for fusion

xpand $1050 \%$ the fraollon of elvillan $\mathrm{A \& O}$ budgols of $D$ dovolod 10 consorvallon and ronowables; omphasia Including sodal solonogg

Includo modost domonstrations of advancud lodinologlo prospocts of long - run loast-cost including oxtornaliti

Support Industrlal enorgy A\&D conters of oxoollanco

Prlorlize programs at National Labs to be consletent will significanlly lncraaso A\&D funde to univar sitles

End-uso Enargy Ellicioncy

Tighton appliarice and bullding allicloricy standards

Establish Industrial B\&D conters of axcollanco lor rosea

Establish ratlngs and standards for lndustrial ocpuipmont molors

Provido adequato finanolal incontlvas for domand.sido if 


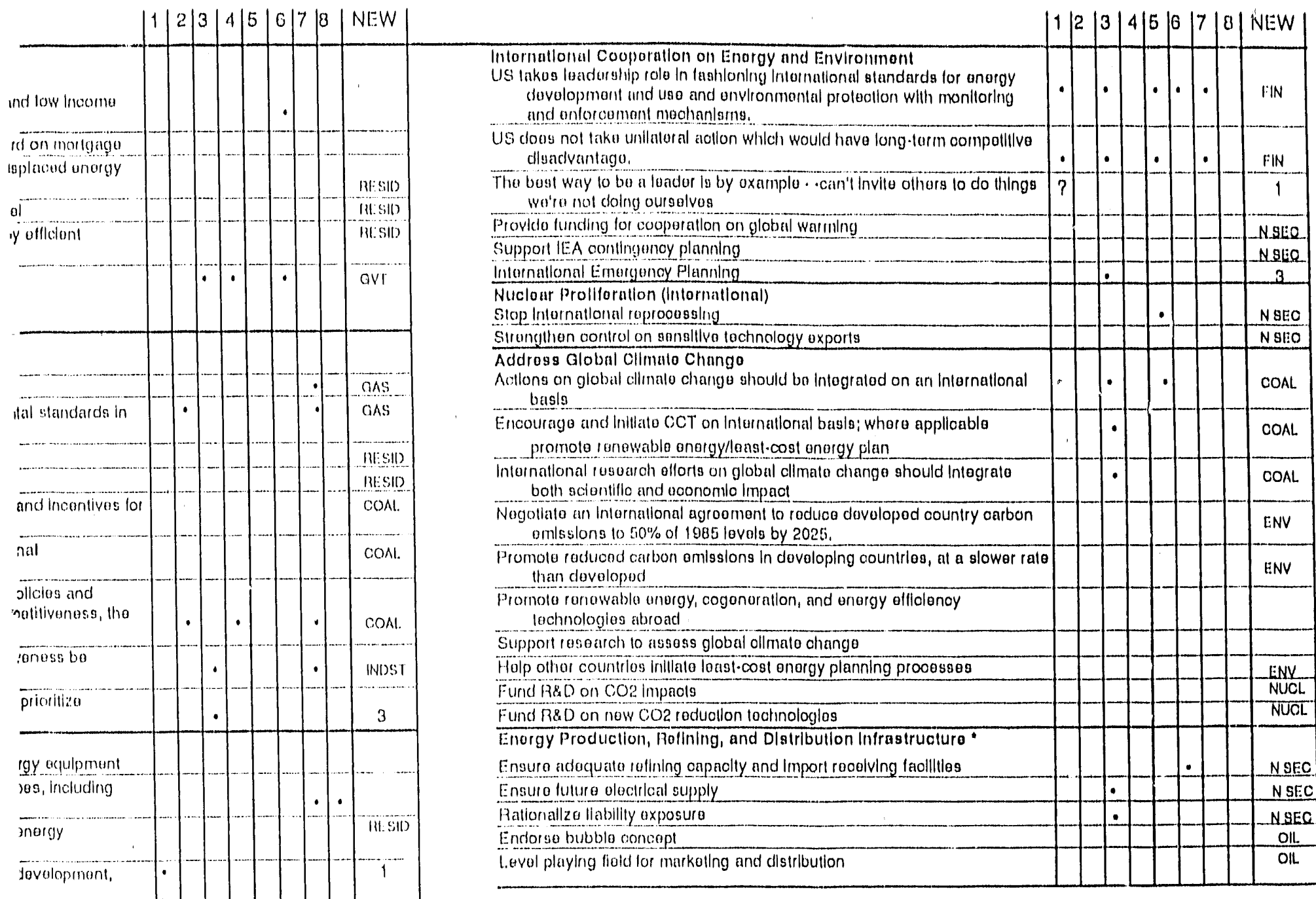

THS CHART LISTS AIL. ENERGY POLICY OPTIONS INCLUDED IN DISCUSSION DUARISG THE NEGOTIATION SEGMENT OF THE NECE. COLUMANS 1 THFOUGH 8 SHOW POLICIES WHAOH WEAE INCLUDED IN AGBEEMENTS AT FACH OF THE EIGHT NEGOTIATION TABLES.

MOST OPTIONS WERE TAKEN FHOM THE "COMPREHENSIVE LIST OF Topics and Policy options for Negotiating a National Enemgy STRATEGY" WHICH, COMPILED FROM A SUIAVEY AND SUPPLEMENTED WITH ADDITIONS FHOM THE SECOND CAUCUS SESSION, WAS PFOVIDED TO PARTICIPANTS FOR NEGOTIATION. SOME OF THE POLICY OPTIONS ON THIS I.IST, HOWEVEA, WERE MODIFIED FHOM THAT LIST OR NEWLY CAEATED DURING THE NEGOTIATION GESSIONS. THE NINTH COLUMN OF THIS MATRIX INDICATES WHICH POLICIES WERE MODIFIED OR CREATED, EITHER DURING CAUCUS SESSION (WITH THE INTEREST GROUP ABBREVIATEO) OR IN NEGOTIATION (WITH THE TABLE NUMBER INDICATED) 


\section{APPENDIX E: PROCESS-ORIENTED COMMENTARIES}

This appendix summarizes (anonymously) the process-oriented comments received after the NECE from participants -- either in response to our survey, or in phone calls or letters. 


\section{Participants of the National Energy Consensus Experiment assessed} its effectiveness in letters, memos, telephone interviews, and a written evaluation form. Their comments address several topics: critique of the process; the success of the event; the possibility of using consensus-building in further development of a national energy strategy, and suggestions on how to implement consensus-building with greatest success.

\section{Comments on the Consensus-Building Process at the NECE}

"Process was good, within time available. Break for dinner -- work again -- write again -- go all night. Materials didn't add much. People went with what they came with. Yes, the process is worth pursuing. We came close, and had to back off. Let's find a way to keep going. Got close because, in part, we were out of time. The producer industry is scared for its life." Do it again with smaller group -- get 2 or 3 negotiating groups, maybe smaller; then get agaregate. Facilitators pretty good - but - they need substantive knowledge."

"Not enough time to discuss and come to consensus with other members of the working group. Also found environmentalist and others highly organized and committed to attaining their agenda -- not very interested in compromise."

"As to the process: I think it is very good; I talked to a lot of people, and no one thought it was a waste of time. BUT there are some procedural and other aspects that created some problems ... among them: the electronic voting glitches evoked a "low level of procedural satisfaction"; you really need a lot more time."

"The overall process was generally good, although a little frustrating that more wasn't accomplished. Given more time in the negotiation sessions, perhaps mutual understanding could have been improved, and that will be the source of progress. Spend less time on defining the issues and more time on discussing them. We went through 1) a questionnair(:, 2) as focus group, 3) a dry-run, and 4) the morning of NECE. all to narrow the list of issues and options, and still weren't very successful. Prior sessions should have been relied upon, and NECE been an all-day negotiation."

"I found the pincess disappointing -- my consensus building group was dominated by four strong personalities and we never really got to any real tradeoff discussion. That greatly frustrated others, especially in the supply group, so we all were displeased by the results of the afternoon session. Our facilitators didn't facilitate -- in fact, they hindered the process. Instead of getting into a discussicn/trade-off mode quickly we spent 1 1/2 hours in a useless exercise of reinventing the wheel of generalities and platitudes. We needed a tough-minded taskmaster to promote interchange, and didn't have it. Alse, the jrou;ns were too big. You get more done with 10-12 people-- 30 was too many." 
"We didn't end up where I expected to or wanted to: the results were too general; this was a real heavyweight group that was exerting "pressure to produce" on facilltator, themselves and each other; there was NOT ENOUGH TIME.

I thought that people were too caught up in the numbers of the survey, and weren't thinking in terms of packages. In our negotiation each person drafted a National Energy Strategy as Secretary of Energy, then passed it around the room to get comments on the back. This was time consuming but got everyone. in the frame of mind to think in terms of packages.

I would have liked to restructure the caucus/plenary so that people had less time in the morning/ more in the afternoon -- though I thought it may have been too much overall. Should restructure the caucus to get people thinking on Trades rather than Positions -- turn the focus early to collaborative thinking -- make "packages" the focus throughout the day."

"I thought the process was very successful, and the resulting packages/agreements were astounding, as I supposes some others did. I did a quick poll of participants and found that they on the whole rated it a 4 on 1-10 (he would have said \pm 7.5 ). I think that there are several reasons for this: though people came up with agreements (a very impressive thing), many of them were obviously phony;

THE DOWN-SIDE - the operational problems and lack of organization in the plenary sessions hurt the legitimacy of the session -- people were upset that Larry was changing rules in the middle of the session. Also, people felt they were getting real, important work done in the caucuses, and felt like the plenary sessions were an intrusion in productive work. The lack of time is not a real excuse for lack of results -- the facilitators told everyone at the outset that time was tight

I thought that the process could be rearranged, maybe getting together 2 or three times over a month, so that the participants could have time to get educated to the topics they are trading, and make a real effort to check with the interest of their constituencies. Then maybe the trades and agreements you come up with would have a little more power and legitimacy."

"People were willing to agree and negotiate the "standard" arguments specific to their industry, but there was an unwillingness to set a goal for the future stability and security of energy supply and need for this country and then make the hard decisions to get us there. I think a major mistake in this process and the experiment was when Susskind changed the rules in the middle of voting on adding the additional list of priorities. I don't think the experiment ever recovered "control" or was able to lend real discipline to the process. Without a simulated crisis or basic feeling of something at risk, folks were not willing to give up anything."

"Too many topics for time available. Facilitators in negotiating session were inconsistent -- 'what do you think of the proposals...no, which ones do you agree with?' Was good to get the diverse group together. Should insist on representation by auto industry, etc. The wrap-up was ineffective -- to many issues with no value order or key items isolated -- we did not reach substantive agreement on a final, all encompassing energy policy -- but prabably identified some good ideas. 


\section{Appendix E - Commentaries}

First night, instructions were very redundant and drawn out...as if in a basic education class. Groups should have time to rank results such as 1. Strong consensus items -. value ordered if feasible, 2. consensus items."

"I Ilke the process, but "experiment" implies that there is some magic to this "divideand-conquer/pressure 1 hour before airport time" technique. Everyone in the business world has used it often. Each industry group must commit more time to the process. The issues are too complex -- what appears to be consensus under pressure becomes disagreement when we have time to contemplate."

"Facilltators did little to promote packages, trade-offs. Too superficial -- no substance. Not enough time -- couldn't bear down. Some were disappointed that their groups were fallure. Facilitators didn't know subject matter -- didn't know interactions of substance."

"I thought we had good dialog and the methodology seemed to be catching hold. Clearly we moved forward and as at the Leesburg meeting, I felt one more half-day might have produced some real movement."

"I found the process fascinating. It was very interesting to observe how different groups interacted, particularly which ones were able to develop and organize a unified position prior to the sessions. We should have spent less time in the caucuses and more time in the negotiating sessions."

"The process worked well. There was the obvious problem of time constraints. In part it was the awkwardness of logistics and materials distribution. But also, because the time was limited, the discussion couldn't get to a level of depth that people could feel really invested. People weren't committed with any strength, in part because there was a lack of understanding about the process, and in part because they could not take the time out of the schedule to educate themselves and each other on issues they didn't fully understand."

"We ended up with a formal process, without "safety." Time limits -- no opportunity for free-flowing conversation."

"Positive, but the subject and number of people were too large for the available time. Also, low income and minority consumer interests were underrepresented."

"The process was effective in establishing interest group priorities, interest group strategies and negotiated consensus. Capable facilitators are an integral part of the process. The most important part of process was establishing personal relationships and trust levels with people from interest groups with differing viewpoints. Whether strategies that were negotiated can be implemented needs to be studied." 


\section{Appendix E - Commentaries}

"The process is a necessity in order to develop agenda lists, caucus to refine the lists; and engage in negotiation to develop trade-offs for agreement."

"Interaction seemed healthy; results encouraging. Capturing the information was very spotty and disappointing."

"Valuable, but biased and probably invalid results due to non-participation by certain industry groups, and over-participation (such as allowing staff to participate and vote) by others."

"Worthwhile and interesting."

"I shared the common feeling that there was not enough time to get everything done. I found the morning sessions, particularly the plenary sessions, a bit cumbersome and long. I thought that everyone would have been amenable to a little less banqueting and a Iittle more preparation. (then again, people always use exactly as much time as they have. Still, I think using the first night would have been helpful.)

There should have been more time allotted for the facilitators to get together on "the process." Some made use of informal time, but felt that some sort of formal break (or breaks) would have helped the participants and given the facilitators a chance to compare notes. It may have helped the group to have facilitators with such distinctively different styles working toward the same goal. "

"Time pressures: low level, chronic confusion detracted. The materials had to get everyone in the same place, no matter what. Too ambitious in scale -- too many people. Tough logistics. Not impressed by general quality of facilitators. Large population + poor facilitation = minimal achievement."

"Excellent process."

"Potentially very constructive. Even if the results are not used in direct formulation of policy, the contact between the various "sides" of the issues certainly was helpful to the participants. Reduce the number of after dinner speeches. They were "preaching to the choir" and detracted from the time avallable for discussion among the special interest groups that followed dinner. The sessions in the auditorium before individual "encounter group" meeting seemed over-bureaucratized. The impression was left that the moderator had an agenda and that our votes didn't meet it, we would keep voting until we did. It perhaps would have been appropriate to just put on the main agenda the asterisked items from each group."

"Worthwhile -- a valuable contribution to short-term consensus building and possible long-term relationship building. Our facilitator wasn't prepared."

"The process is useful, if "only" to get opposing groups to talk. However, the process is flawed, perhaps fatally, by being too unformed and not delineating the range of options." 


\section{Appendix E - Commentaries}

"Massive undertaking -- completed with deep level of commitment, skill and good humor. Quality of medlators was mixed -- some excellent, some not so good -. strength of mediator made the difference, in some cases, in the quality of the workgroup experience."

"Useful, but perhaps over-ambitious."

"Necessary, but rough."

"I thought far too much time was spent in the morning preparing for negotiation, much of which was unproductive. The afternoon went very well, and was very productive. Spend less time with rigid procedures for preparation."

"As a whole, the process worked better that I had anticipated. I found merit in the compressed schedule. I thought the too-long speeches on the first night set a bad example for the tight schedule on the following day. The plenary sessions didn't work -- they took too much time and tended to "disconnect" people from the work they had been doing in smaller sessions, and the changing of the groundrules in the first plenary caused significant grousing and some question as to whether the proceedings were "stacked" toward one group or another. I would have built some short breaks into the schedule to give people a bit of a rest without taking away from the sessions."

\section{Consensus-Building as a Part of the National Energy Strategy}

"The negotiation group demonstrated that people coming together can work. There was enough substance there, and enough agreement. Shows that DOE has a position to say "we do have a blessing to move forward with the following:" If they recognize that they have a winning hand, we'll get something out of it. Let them lay claim to it -. bring it in -. use outsiders' credibility to their advantage."

"Yes, use consensus-building for a national energy strategy, with informed leadership groups as in NECE. There are a lot of myths, misperceptions, misinformation, and emotion surrounding energy issues, and a process to establish a common base of facts could lead to significant mutual understanding and progress toward consensus.

How? 1) Assemble committed and capable groups such as at NECE, but reduced in size and at the knowledgeable staff level rather than CEO level so the appropriate time might be devoted to the process. 2) Give every participant the opportunity for about a 15minute opening presentation of what he or she would most like to tell the group. 3) Start talking, with a facilitator to allocate time fairly, to keep the process on track, and to focus on particular conflicts." 
[Use consensus for NES?] "Not in the way we did it -. we would have to obtain the services of people who understand the language and buzzwords of the energy industry. Also you must have people to direct the show who can bring out the true feelings of the participants." [How?] "Everyone brings things to the table that he must have in order to protect his groups interest. As long as he has something else to trade, the process works. So you have to keep the various constituencles at the table and put them in the horse trading mood -- I still think that it can be done, but not in public where each participant has to be able to preserve his reputation with his own supporters."

"Get commitment for Summit of 15-20 people -- 3-5 days of packaging. Then direct request thru Watkins or Bush. "The improbable coalition of interested parties." $A$ proven methodology, and useful. The AEAC could become the general contractor for DOE - If Watkins asked and selected facilitators -- It could work. AEAC should finalize, wrap up, and turn over, unless DOE wants to fund to sustain through this year."

[support consensus bldg for NES?] "Yes -- but on a smaller scale, more topic specific, and more of a requirement for groups to have to commit to a long-term strategy. There comes a point when federal policy-makers are just going to have to make hard decisions that folks will have to live with. These top-level people can "consensus" forever and never establish policy (this was a necessary and important exercise, but it has made its contribution. A "further" exercise or pursuit would be unproductive.)"

"Consensus bullding is not bad way to provide input to DOE, but should not be the "final authority" on National Energy Strategy. The final consensus building must be with broad guage and wise representatives of government and industry."

[use of consensus bldg in NES?] Yes. If the process is thorough and for a purpose other than the political expedient of appearing to care about the results -- while fully intending to ignore them. [how?] Your stated purpose has already answered this. Divergent and incompatible interest groups will continue to present a cohesive strategy. Compromise is essential. It's better to have a less than perfect strategy than no strategy at all.

"There are real political problems with this approach -- but that doesn't mean it can't be done. It should be done.

"This is the right process -- no issue exists in isolation, as DOE seems to think. Get people together -- trade issues -- cost it out - then make decisions. Consultations and negotiations would be helpful to DOE. Experiences varied widely. Level of representation was appropriate -- need the stakeholders, with technical backgrounds. You can only negotiate when you've got the guys with the clout. AEAC did. More groundrule setting would be needed for ceal negotiating. You'd need to limit political image. Hard to open up policy process before you've got "stakes driven into the ground." Real, rigid groundrules -- everything negotiable; confidentiality; strong sanctions against compromising integrity."

"We need to see more principles from the government -- not just watchers, but players. If the administration and the Congress aren't ready to play, there will be no game." 
[consensus in the NES?] "Yes, although I suspect we're really talking about a combination of traditional $D-M$ with consensus bullding used to smooth out rough spots. There is little doubt in my mind that those who have the Interests of creating "good national energy policy' must work together, or those with more defined "self-interests" will divide and conquer in ways not in national best interest."

"It is imperative to get people to understand areas of agreement prior to taking positions of opposition based on "who the other side is" rather than the facts of their position. The problem lies in getting enough people to participate to be sure that diverse viewpoints are recognized. We should have spent less time in the caucuses and more time in the negotiating sessions. The real value of an exercise like this lies in cross-fertilization, not in talking with ourselves."

"Consensus-building helps, it already has. Can not resolve everything."

"The NECE was staged. But I stlll think it could work. A wonderful experience, in sense of building the "networking" process -.. conversations about how to have conversations. We needed people in bermuda shorts, eating hot dogs, expressing views. Get stuff on paper only late in the game."

"Consensus bullding could serve as guidance for areas deserving priority attention."

"1) Allow more time for industry group strategy making, and 2) Better capture of the agreements made at the negotiation table is necessary. Conditions added to policy statements were not well captured or reported. This needs to be improved for participants to gain trust in the process. I support a consensus buliding process. At some point, different interest groups must come to an understanding that developing adequate energy and electricity supplies for a healthy economy and a healthy environment is a common objective. We need to hear other people voice their perspective, whether it be from a supply or demand-side orientation, and develop a consensus that is equitable to reasonable concerns.

"A process like the one used at Princeton is helpful because it makes interest groups establish priorities and speak with one voice. Internalization of environmental costs and least-cost planning are two principles that will undoubtedly be used in developing energy policy.

"A consensus process that could be used to establish NES is to have representatives of each interest group develop a common, consistent methodology for least-cost planning and internalization of environmental costs. With an agreed evaluation methodology, acceptable energy strategies can then be developed."

"It is difficult to separate personal and professional preferences and concerns when dealing with energy. Participants need to be selected based on their ability to represent their group's overall interests. Consensus building is essential considering the diversity of interests of each constituency and the traditional adversarial roles of those interest groups. It can lead to win-win situations instead of compromise -- everyone's participation increases the probability of a successful national policy implementation." 
The process needs much better information capture - perhaps TV or audio tape; perhaps "stenos." Process may now fall apart since the written word may not be what people recall was sald. Right levels of right organizatlons need to be there. [consensus bullding for NES?] The Jury is still out with me. There is hope, we should still continue to try;

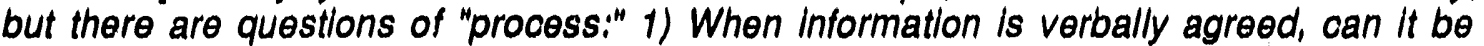
"captured?" 2) will the organizations/Industries behind the Individual support the individual? and 3) are all members of the issues really involved? It would help DOE know what factions' leaders belleve can work. Would help "sell" the strategy."

"Delegates must be selected to represent all Interests and input and voting appropriately weighed. Consensus bullding in NES could work, with beiter guldelines. Each interest group gets the opportunity to understand the issues which are important to the "other side," and why, and can attempt to appropriately accommodate those issues."

"Without such a process, several viable options may not be considered. You need fower people, fewer groups, more sense that it would make a difference. It might force extreme views of environmentalists and others into compromise."

"It is very important to keep non-AEAC people involved in the discussion and debate maybe have another "snapshot" debate session where people pick up these pollcles and talk some more. It is very important not to let the debate lose this momentum now that we have people talking."

"Could work with smaller groups, in both caucus and negotiations, and some improvement in facilitation, maybe more focussed \& rigorous engagement in substantive issues. Plus more time. Greater selectivity as to who would be there -- more focused agenda, designed to highlight fundamental questions, focusing systematic and comprehensive surfacing of key issues. Thought well of it throughout -- especlally in light of the experimental nature. No one who participated would be able to think about these issues in the same way they had previously. We will take this into account, in the future.

"If DOE were smart, they would take this primitive beginning, and figure out a way to get ongoing efforts to delineate issues this way, and institutionalize it. Perhaps create a national energy/environmental conference, with sufficient funding, to allow periodic review and progress? If fundamental valldity in concept, might be accomplished in a decade. I hope we can hand it one to the Department of Energy -- and let them help our child reach adolescence and maturity."

"Follow-up now with DOE -- offer to convene participants and DOE's NES team for further development of NES. Consensus building will develop support for a strategy which will be required to implement the strategy nationwide. It brings divergent groups together and forces a strategy development."

"It is more effective to have the interested, knowledgeable groups negotiate among themselves than to do so indirectly -.- either through the legislative process or by using the executive branch as a distant mediator. It tends to move the groups closer together 
much more rapidly and to significantly improve true understanding of the different positions.

"Consensus bullding is essentlal to obtaining publlo support for polloy. For a National Energy Strategy to be effective it has to be supported by the public. Sinoe speclal interest groups are assumed to have speclalized knowledge, publio opinion is molded by those groups. If those groups can develop a consensus, the hard part of developing a NES is probably behind us."

"Allow more time for the negotiating groups -- perhaps include a meal together as well to increase the bonding. Allow time for participants in each group to sign off in writing on the group's agreements (exact wording). Evaluate faclitators to be sure they are qualified and prepared.

Consensus bullding could be valuable to the NES - as input, not for the final product. The Strategy must be based on careful and complete analysis of realities, feasibilities, constraints - not bartering. Consensus bullding shows which policles are more or less likely to be broadly acceptable across stakeholder groups. Increases acceptability of policies by bringing groups closer together in the 'search for common ground."

"More specific goals and objectives MUST BE DEFINEDI Both qualltative and quantitative guidelines should be established -- put "strategic' and "tactical' options in separate groups. Rank priorities in near-term, long-term enterprises. Define RISKS of doing or NOT dolng something."

[suggestions?] "1. More time in the working groups. 2. Better coaching of constituency group on what to expect. 3. More time to read background materials on each topic." [consensus in NES?] "Yes, if each constituency group had only ene vote -- in my working group 3 or 4 persons had the same agenda. Energy production had two (of diverse backgrounds.)" [how?] "Consensus bullding, If done right, can inject the cost of alternative strategies, and the timing of alternatives. Something few have an appreciation for."

"I'm very concerned about the focus on "trades/agreements" versus "possible areas of agreement." I think it is very important to frame any presentation and/or dlscussion of the findings at the NECE as tentative, concessional, and transittonal. Part of the frustration during and after the session was the suspicion by some that, though they knew the "agreements" made were tentative, some others were taking them as real concessions and real agreement.

"I don't want TRADES to become a "Grall" of this search. Make sure it is very clear that we are not asking anyone to negotiate away their princlples. Rather, it should be made clear that people should be prioritizing their preferences with a clear sense of what they are willing to bargain on, and working out a concession/counter-concession from that starting point.

"When reporting the results of this session, it is very important not to make more out of it than there was -. "show a sow's ear as a sow's ear, not a silk purse." If you force the proposition that there was decisive agreement on real issues, you're going to lose support for the very real-though-tentative results we did get.

"The results of this session can work very well as a "first step" to something else -. don't try to re-run to get the results you were hoping for. Use these results and get a group of people together -. hopefully smaller, and hopefully all people who participated 
In NECE or people of a higher level from similar interests ... to make something out of the 'product' of this. Make sure when you present that product that you communicate that 'these are not agreements ... there was agreement that they are very important toplos to discuss."

"Consensus bullding creates workable environment to move national debate. Consinsus allows stakeholders to negotlate in terms of strategles in a produotive/non-adveisarial environment. We do not have the time to delay action on developing a national energy strategy."

"Elther expand the time or decrease the issues. Allow more in-depth disoussion. Consensus bullding is a useful tool for determining which issues are most important to varlous constituericles. Subsequently, resources can be better allocated. Aotive participation by Congressional and Executive Branch representatives a must."

"Work from packages have (milk what have and expand from $t_{\text {t. }}$ ) Personal contact is a pre-condition for bargaining. Consensus bullding can break down irrelevant barrlers."

"I think many of the interests involved in national energy pollcy don't understand the positions of their opponents. Negotlations develop better understanding, and more opportunities for compromise."

"Put a report together of some recommendations of 'the kinds of packages that people who are reasonably well-informed would like to have addressed.' It is very important to frame the report that way, as nothing more than that - and as absolutely nothing concrete in terms of 'packages' or 'agreements' or 'negotlated pollcy options." 
APPENDIX F: LISTS OF PARTICIPANTS and the 12 CONSTITUENT GROUPS 


\section{NATIONAL ENERGY CONSENSUS EXPERIMENT Participants, Observers, and Staff}

Mr. Joseph J. (Joe) Adams, Executive Assistant to the Chairman/Union Pacific Rallroad Company

Mr. Larry Aggens, Consultant/L. Aggens \& Associates

Ms. Abby Arnold, Associate/CMI/Conflict Management Project

Ms. Mary Babson, Manager/Arthur Andersen de Co:

Mr. Edward V. Badolato, President and CEO/Contingency Management Services

Ms. Debble Balmer, Staff Assistant/American Energy Assurance Council

Mr. Robert C. Barrett, Program Officer/The William \& Flora Hewlett Foundation

Mr. Charles F. Baxter, Director/U.S. Department of Energy, New York Support Office

Mr. Michael L. Beatty, Executive lice President and General Counsel/The Coastal Corporation

Mr. Howard Bellman, Mediation \& Arbitration

Mr. A. Edgar Benton, Partner/Holme Roberts \& Owen

Mr. Peter A. A. Berle, President/The Audubon Society

Mr. David J. Berteau, Principal Deputy Assistant Secretary for Procurement \& Logistics/U.S. Department of Defense

Dr. Jan Beyea, Senior Scientist, Audubon/National Audubon Society

Brigadier General James E. Bickford, Commander/Defense Fuel Supply Center

Mr. Edward J. Biddle, Deputy Director, Contracting \& Production/Defense Fuel Supply Center

Mr. Robert T. Birdsong, President/Bird Oil Corporation

Dr. Ann S. Bisconti, Vice President, Research \& Program Evaluation/U.S. Council for Energy Awareness

Mr. P. Marty Bitter, Manager, Policy Analysis-Government Affairs/Chevron U.S.A. Inc.

Mr. Linden Blue, Vice Chairman/General Atomic

Mr. Merle L. Borchelt, Chairman and CEO/Central \& Southwest Corporation

Mr. William H. (Bill) Bowker, Executive Assistant, Governor's Office for Coal \& Energy/Keniucky Coal Office

Mr. Peter A. Bradford, Chairman/New York Public Utilities Commission

Mr. David S. Broder, National Political Correspondent/The Washington Post

Dr. E. C. (Tip) Brolin, Acting Director/Princeton Plosma Physics Laboratory

Mr. Douglas R. Brookman, Senior Manager \& Mediator/American Energy Assurance Council

Mr. Edmund W. Burke, Executive V.P., Law \& Governmental Affairs/Burlington Northern Railroad

Mr. Thomas G. Burns, Manager, Economics Staff, Corporate Planning \& Analysis/Chevron Corporation

Mr. W. A. (Bill) Cameron, Vice President - Government Operations/McDermott, Inc./Babcock \& Wilcox Co.

Ms. Susan Carpenter, Mediator/Susan Carpenter Associates 
M: Phillip J. Carroll, Executive Vice President, Administration/Shell Oil Company

Mr. Francis C. (Butch) Cash, Executive Vice President/Marriott Service Group

Mr. Paul Centolella, Senior Energy Policy Advisor/Ohio Consumer Council

Mr. Warren P. Chernock, Vice President, Advanced Systems/Combustion Engineering, Inc.

Mr. Steven D. Chesebro', Executive Vice President/Tenneco Gas

Mr. Roger E. Clark, Chief Counsel/Pennsylvania Energy Office

Mr. Donald W. (Don) Clayton, President \& CEO/Meridian Oil, Inc.

Mr. Jarvis D. Cotton, Director, Strategic Operations Department/Westinghouse Electric Corporation

Mr. William Counsil, Vice-Chairman/Texas Utilities

Mr. Donald K. Craft, Director of Business Development/Amax Coal Industries, Inc.

Mr. Derrick Crandall, Executive Director/American Recreation Coalition

Mr. James Creighton, President/Creighton \& Creighton

Mr. Jeff Cruikshank, Kohn \& Cruikshank

Mr. Sheldon A. Cunningham, Director of Strategic Operations/Kerr-McGee Coal Corporation

Mr. Dan D'Armond, Press Secretary to Deputy Secretary/U.S. Department of Energy

Mr. James M. Dalglish, General Manager - North Dakota Region/Northern States Power Company

Mr. Charles N. Davenport, Chief Executive Officer/Seawest Energy Group, Inc.

Dr. Brenda S. Davis, Visiting Fellow/Woodrow Wilson School

Mr. Keith Decie, Senior Account Executive/Kearns \& West, Inc.

Mr. Gerald L. Decker, Chairman of the Board/Decker Energy International

Ms. DeeDee Delano, Office Manager/American Energy Assurance Council

Mr. Jerome Delli Priscoli, Senior Policy Analyst, Institute for Water Resources/U.S. Army Corps of Engineers

Mr. Richard E. Disbrow, President \& Chief Executive Officer/American Electric Power Service Corporation

Mr. Richard (Dick) Doubrava, Manager of Governmental Affairs/Delta Air Lines, Inc.

Mr. William R. Drake, Vice President/National Institute for Dispute Resolution

Dr. Charles K. Ebinger, Vice President/International Resources Group, Lid.

Mr. L. C. (Larry) Edwards, Director, Strategic Planning Division/Tenneco Gas

Mr. Wesley C. Engstrom, Manager, Energy Office/Boeing Company

Mr. Daniel C. (Dan) Esty, Special Assistant to Administrator/Environmental Protection Agency

Mr. John K. (Jack) Evans, Advisor to CEO \& Chairman/Pacific Resouices, Inc.

Mr. Craig Eymann, Developer/Cedar Creek Development

Mr. Jerry M. Eyster, Vice President, Business Development/A. T. Massey Coal Company, Inc.

Mr. David Fairman, ENDISPUTE, Inc.

Dr. Barbara C. Farhar, Senior Social Scientist/SERI, Washington Office

Mr. Thomas A. (Tom) Farkas, Energy Program Manager/National Association of Home Builders

Mr. Harold B. Finger, President \& CEO/U.S. Council for Energy Awareness 
Mr. Allan Fitzsimmons, Special Assistant to Deputy Under Secretary/U.S. Department of Energy

Ms. Cheryl M. Foley, Vice President \& General Counsel/Public Service Indiana Energy, Inc.

Mr. Douglas Foy, Executive Director/Conservation Law Foundation of New England

Mr. George T. Frampton, President/The Wilderness Society

Mr. H. Allen Franklin, President and CEO/Southern Company Services, Inc.

Mr. Jan H. Freeman, Executive Director/Pennsylvania Energy Office

Mr. Clark W. Gellings, Director, Customer Systems Division/Electric Power Research Institute

Mr. Dominic M. Geraghty, Director, Office of Corporate \& Strategic Planning/Electric Power Research Institute

Mr. Joel D. Getzendanner, Program Director/The Joyce Foundation

Mr. Oswald W. J. Girard, Deputy Assistant Director for Engineering Geology, U.S.G.S./U.S. Department of Interior

Ms. Paula W. Gold, Senior Vice President/New England Electric System

Mr. David B. Goldstein, Energy Program Co-Director/Natural Resources Defense Council

Mr. Lawrence J. Goldstein, Executive Vice President - Trustee/Petroleum Industry Resource Foundation, Inc.

Ms. Anne E. A. Golightly, V.P., Strategy \& Business Development/Marriott Service Group

Ms. Laurie D. Goodman, Legislative Assistant/Office of Senator Alan Simpson

Mr. Terry R. Griffin, Vice President/Texas Utilities

Mr. Richard J. (Dick) Gross, Legal Counsel/State of North Dakota

Dr. Robert I. Hanfling, Sen or _Advisor/Putnam, Hayes \& Bartlett, Inc.

Mr. Philip Harter, Esq., Philip J. Harter Assoc.

Ms. Tina C. Hobson, Executive Director/Renew America

Mr. Dennis Hupe, Vice Presideni/Kansas Farm Bureau

Dr. Robert C. Iotti, Vice President, Advanced Technology/EBASCO Services Incorporated

Mr. Ralph Izzo, Director of Programs/Concord Resources Group

Mr. John G. Jenkins, President/American Energy Assurance Council

Mr. Jeffrrey A. Jones, Director of Energy Policy/U.S. Department of Defense

The Honorable Thomas H. Kean, President/Drew University

Mr. 'Thomas B. Kelly, Managing Partner, Management Services/Arthur Andersen \& Co.

Ms. Margaret (Meg) J. King, Project Director/American Energy Assurance Council

Mr. Donald P. Kratz, Senior Federal Affairs Counsel/AMAX Inc.

Mr. Thomas R. Kuhn, President/Edison Electric Institute

General Richard L. Lawson, President/National Coal Association

Ms. Sheila A. Leahy, Deputy Director/Council of Great Lakes Governors

Mr. Marc R. Ledbetter, Senior Associate/American Council for an Energy-Efficient Economy

Ms. Kathryn Lester, Staff Assistant/American Energy Assurance Council

Mr. R. N. (Roy) Levitch, Planning Advisor, Corporate Planning/Shell Oil Company

Mr. Peter B. (Pete) Lilly, President/Kerr-McGee Coal Corporation 
Mr. Amory B. Lovins, Director of Research/Rocky Mountain Institute

Ms. L. Hunter Lovins, President/Rocky Mountain Institute

Mr. Thomas A. Lueck, Manager - Fuel Administration/Northwest Airlines

Mr. Charles Mann, Writer/Atlantic Monthly

Ms. Melissa Margetts, Public Affairs Specialist/U.S. Environmental Protection Agency, Region II

Dr. Kleber S. Masterson, Vice President/Booz-Allen \& Hamilton

Dr. Jessica Tuchman Mathews, Vice President/World Resources Institute

Mr. Paul E. Mawn, Partner/Temple, Barker \& Sloane, Inc.

Mr. Bruce M. McCarthy, President/BMc STRATEGIES, INC.

Mr. David McDermitt, Vice President/BMc STRATEGIES, INC.

Mr. Bruce McElvein, Special Assistant to Assistant Secretary/U.S. Department of Interior

Mr. John McGlennon, President/ERM-New England, Inc.

Mr. James Menning, Northern Natural Gas Company

Mr. Jeremy Metz, Director, Energy, Materials \& Technoiogy/American Paper Institute

Mr. Christopher Moore, CDR Associates

The Honorable W. Henson Moore, Deputy Secretary/U.S. Department of Energy

Dr. Theodore H. Moran, Director, Landegger Program in International Business Diplomacy/Georgetown University

Mr. Richard D. Morgenstern, Director, Office of Policy Analysis/U.S. Environmental Protection Agency

Mr. James D. Mottley, Manager, Forecasting and Analysis/Westinghouse Electric Corporation

Mr. Ken Murphy, Executive Director/Energy Environment Study Institute

Mr. Roger F. Naill, Vice President, Planning/Applied Energy Services Corporation

Mr. Peter W. Niebauer, Acting Deputy Assistant Secretary/U.S. Department of the Interior

Mr. Raymond J. O'Connor, Vice President and Senior Banker/Citibank, N.A.

Mr. Robin O'Malley, Senior Policy Analyst/Council on Environmental Quality

Mr. Richard P. (Dick) O’Neill, Director, Office of Economic Policy/Federal Energy Regulatory Commission

Mr. William Perry Pendley, President and Chief Legal Counsel/Mountain States Legal Foundation

Mr. Raymond N. Plank, Chairman and CEO/Apache Corporation

Mr. Ray Poage, Managing Partner/Peat Marwick \& Main

Ms. Susan Podziba, ENDISPUTE, Inc.

Mr. Gene Pokorny, President/Cambridge Reports Inc.

Mr. Darryle L. Powers, Vice President - Purchasing/Northwest Airlines

Mr. Joshua Reichert, Program Director for Conservation \& the Environment/The Pew Charitable Trust

Mr. Eric H. Reichl, Director/Radian Corporation

Mr. Robert O. (Bob) Reid, Vice President, Planning/Colorado Interstate Gas Company

Mr. Oliver G. (Bob) Richard, President/Northern Natural Gas Company

Mr. Alan H. Richardson, Assistant Executive Director/American Public Power Association

Mr. James W. (Jim) Rosborough, Lecturer/Rice University

Mr. Michael M. Sample, Vice President Corporate Relations/PSI Energy, Inc.

Mr. Perkins D. Sams, Chairman/Banner Energy, Inc.

Mr. William H. Satterfield, Partner/Balch \& Bingham 
Mr. Howard H. Shafferman, Chief of Staff \& Counselor/Federal Energy Regulatory Commission Ms. Patricia J. Shorr, Vice President/St. George Capital Corporation

Mr. Conrad Simon, Director, Air \& Waste Management Division/U.S. Environmental Protection A Mr. Larry D. Simpson, General Manager/Northern Colorado Water Conservation District

The Honoruble George A. Sinner, Governor/State of North Dakota

Mr. Edward Skloot, Executive Director/SURDNA Foundation

Mr. Gavin P. Smith, Vice President, Law \& Governmental Affairs/Meridian Oil, Inc.

Brigadier General Juhn F. Sobke, Commander and Division Engineer/U.S. Army Corps of Eng.

Dr. Robert H. Socolow, Director, Energy and Environmental Policy Center/Princeton University

Mr. Robert B. Spears, Chairman/Spears \& Associates, Inc.

Mr. William A. Spratley, Consumers' Counsel/Ohio Office of Consumers' Counsel

Mr. H. Leighton Steward, Chairman, President and CEO/Louisiana Land \& Exploration Company

Mr. Charles D. Strang, Chairman of the Board/Outboard Marine Corporation

Mr. James Streeter, Special Assistant to Assistant Secretary/U.S. Fish \& Wildlife Service

Mr. James N. Sullivan, Vice Chairman/Chevron Corporation

The Honorable Michael J. Sullivan, Governor/State of Wyoming

Mr. Lawrence E. Susskind, MIT Department of Urban Studies \& Planning

Mr. Leonard Sylk, Chairman/Shelter Systems

Mr. John Elting Treat, Vice President/Booz-Allen \& Hamilton

Mr. Eric E. Van Loon, Executive Vice President/ENDISPUTE, Inc.

Mr. William R. Wahl, Vice President, Corporate Planning/AMAX Inc.

Mr. Stephen A. Wakefield, General Counsel/U.S. Department of Energy

Mr. Michael H. Walsh, Chairman and CEO/Union Pacific Railroad Company

Ms. Anna L. West, Partner/ Kearns \& Wcst, Inc.

Mr. M. Arnold Wight, President/Principled Negotiation, Inc.

Mr. Mason Willrich, President and CEO/PG\&E Enterprises

Mr. James L. Wolf, Executive Director/The Alliance to Save Energy

Mr. Robert E. (Bob) Wood, Vice President - Public Affairs/MDU Resources Group, Inc.

Mr. H. J. (Jack) Young, Senior Vice President/Edison Electric Institute

Dr. Eugene W. Zeltmann, Manager, Trade and Industry Associations/Genera'

Mr. James W. Ziglar, Former Assistant Secretary, Water \& Science/U.S. ${ }^{\boldsymbol{r}}$ 


\title{
NATIONAL ENERGY CONSENSUS EXPERIMENT 12 Constituent Groups
}

\author{
Alternative Energy \\ Coal \\ Consumers: Industrial, Agricultural and Transportation \\ Consumers: Residential, Commercial and Service \\ Electrical \\ Environmental \\ Financial \\ Gas \\ National Security \\ Nuclear \\ Oil
}

State \& Local Government 
APPENDIX G: AEAC BOARD OF DIRECTORS 


\section{AEAC BOARD OF DIRECTORS}

Mr. Michael L. Beatty

Executive V.P. and General Counsel

The Coastal Corporation

Coastal Tower

Nine Greenway Plaza

Houston, Texas 77046-0994

(713) 877-1400

Mr. A. Edgar Benton

Attorney at Law

Holme Roberts \& Owen

1700 Lincoln Street, \#4100

Denver, Colorado 80203

(303) 861.7000

Dr. Jan Beyea

Director of Environmental Energy Policy

National Audubon Society

950 3rd Avenue

New York, New York 10022

(212) 832-3200

Mr. Robert T. Birdsong, Jr.

C.E.O.

Bird Oil Corporation

1801 California Street, \#4500

Denver, Colorado 80203

(303) 292-3344

Mr. Stephen D. Chesebro'

President and C.O.O.

Tenneco Gas

1010 Milam Street, 16th Floor

Houston, Texas 77252-2511

(713) $757-7600$

Dr. Charles K. Ebinger

Vice President

International Resources Group, Ltd.

1400 Eye Street, N.W., \#700

Washington, D.C. 20005

(202) $289-0100$
Ms. Tina Hobson

Chairman of the Board

Renew America

1400 16th Street, N.W., \#710

Washington, D.C. 20036

(202) 232-2252

Mr. Charles R. Imbrecht

Chairman

California Energy Commission

MS 31 - 1516 Ninth Street

Sacramento, California 95814

(916) 324-3000

Mr. John G. Jenkins

President

Glynsong Holding Company

1801 California Street, \#4500

Denver, Colorado 80202

(303) $292-3344$

The Honorable Thomas H. Kean

President

Drew University

36 Madison Avenue

Madison, New Jersey 07940

(201) 408-3000

Mr. Thomas B. Kelly

Managing Director, Northern California Arthur Andersen \& Co.

Spear Street Tower

One Market Place

San Francisco, California 94105

(415) $546-8400$

Ms. L. Hunter Lovins

President

Rocky Mountain Institute

1739 Snowmass Creek Road

Snowmass, Colorado 81654-9199

(303) $927-3851$ 
Dr. Jessica T. Mathews

Vice President

World Resources Institute

1709 New York Avenue, N.W., \#700

Washington, D.C. 20006

(202) 638.6300

Mr. Raymond N. Plank

Chairman and C.E.O.

Apache Corporation

1700 Lincoln Street

Denver, Colorado 80203

(303) $837-5100$

Mr. Jack Riggs

Staff Director

U.S. House Subcommittee on Energy and Power

2nd and D Streets, S.W., \#H2-331

Washington, D.C. 20515

(202) 226-2500

Mr. John A. Schuchart

Chairman and C.E.O.

MDU Resources Group, Inc.

400 North Fourth Street

Bismarck, North Dakota 58501

(701) 222-7900

The Honorable George A. Sinner

Governor

State of North Dakota

Capitol Building

Bismarck, North Dakota 58501

(701) $224-2200$

The Honorable Peter P. Smith

U.S. Congressman

State of Vermont

1020 Longworth House Office Building

Washington, D.C. 20515

(202) $225-4115$

Dr. Robert H. Socolow

Director, Energy and Environmental

Policy Center

Princeton University

H102 Engineering Quad

Princeton, New Jersey 08544

(609) 258-5446
The Honorable Michael J. Sullivan

Governor

State of Wyoming

Capitol Building

Cheyenne, Wyoming 82002

(307) 777-7434

Mr. William R. Wahl

Vice President

AMAX, Inc.

1819 L Street, N.W., \#300

Washington, D.C. 20036-3895

(202) 466-6966

Mr. J. Robinson West

President

The Petroleum Finance Company. Ltd.

1140 Connecticut Avenue, \#700

Washington, D.C. 20036

(202) 872-1199

Mr. Mason Willrich

President \& C.E.O.

PG\&E Enterprises

77 Beale Street, 32nd Floor

San Francisco, California 94106

(415) $291-6410$

Mr. James L. Wolf

Executive Director

The Alliance to Save Energy

1725 K Street, N.W., \#914

Washington, D.C. 20036

(202) 857-0666

Mr. James W. Ziglar

Managing Director

PaineWebber Incorporated

1120 20th St., N.W., \#400

Washington, D.C. 20036

(202) $887-6000$ 
APPENDIX H: AEAC MANAGEMENT TEAM AND STAFF

ค 


\section{NATIONAL ENERGY CONSENSUS EXPERIMENT}

\section{Management Team and Staff}

\section{American Energy Assurance Council}

Margaret J. King

Executive Director

American Energy Assurance Council

1700 Lincoln Street, 20th Floor

Denver, Colorado 80203

(303) 837-5117

DeeDee Delano

Manager of Operations

American Energy Assurance Council

1700 Lincoln Street, 20th Floor

Denver, Colorado 80203

(303) 837-5117
Douglas R. Brookman

Senior Manager and Mediator American Energy Assurance Council 5900 York Road, Suite 3

Baltimore, Maryland 21212

(301) 323-4006

Consultant to AEAC

Lawrence E. Susskind

Director - Public Disputes Program

Program on Negotiation

Harvard Law School

1563 Massachusetts Avenue

Cambridge, Massachusetts 02139

(617) 253-2026

\section{ENDISPUTE, Inc.}

Eric Van Loon

Executive Vice President

ENDISPUTE, Inc.

955 Massachusetts Avenue, Suite 700

Cambridge, Massachusetts 02139

(617) 868-0200

David Fairman

Associate

ENDISPUTE, Inc.

955 Massachusetts Avenue, Suite 700

Cambridge, Massachusetts 02139

(617) 868-0200
Susan Podziba

Associate

ENDISPUTE, Inc.

955 Massachusetts Avenue, Suite 700

Cambridge, Massachusetts 02139

(617) $868-0200$ 
Kearns \& West, Inc.

Kenneth Kearns

Principal

Kearns \& West, Inc.

1666 Massachusetts Avenue, Suite 5

Lexington, Massachusetts 02173-5313

(617) 862-6551

Ann Getman

Director of Account Services

Kearns \& West, Inc.

1666 Massachusetts Avernue, Suite 5

Lexington, Massachusetts 02173-5313

(617) $862-6551$

Keith Decie

Senior Account Executive

Kearns \& West, Inc.

1825 I Street, N.W., Suite 400

Washington, D.C. 20006

(202) $429-2055$
Anna L. West

Principal

Kearns \& West, Inc.

50 Osgood Place, Suite 230

San Francisco, California 94133

(415) $391-2100$

Stephen J. Astle

Senior Account Executive

Kearns \& West, Inc.

50 Osgood Place, Suite 230

San Francisco, California 94133

(415) $391-2100$

\section{Kohn - Cruikshank}

Jeffrey Cruikshank

Partner

Kohn - Cruikshank

7 Harris Avenue

Boston, Massachusetts 02130

(617) $522-3736$
Patricia Toland

Writer/Researcher

Krohn - Cruikshank

7 Harris Avenue

Boston, Massachusetts 02130

(617) $522-3736$ 


\section{APPENDIX I: PROJECT SPONSORS}

The American Energy Assurance Council would like to thank the following organizations and indlviduals, without whose support our continuing search for common ground on national energy strategy would not have been possible. 


\title{
AEAC CONTRIBUTORS
}

\section{CONTRIBUTIONS GREATER THAN $\$ 100,000$}

Apache Corporation

The William \& Flora Hewlett Foundation

\section{CONTRIBUTIONS FROM \$50,000-\$99,999}

Chevron, U.S.A.

The Joyce Foundation

National Institute for Dispute Resolution

The Pew Charitable Trust

Shell Oil Company

Ternneco Gas

U.S. Department of Energy

\section{CONTRIBUTIONS FROM $\$ 25,000-\$ 49,999$}

\author{
AMAX, Inc. \\ Arthur Andersen \& Co. \\ Coastal Corporation \\ Coopers \& Lybrand \\ Northern States Power Company \\ Alida Rockefeller "Charitable Lead Trust \#1 \\ SURDNA Foundation \\ U.S. Army Corps of Engineers \\ U.S. Department of Defense \\ Westinghouse Electric Corporation
}




\title{
CONTRIBUTIONS FROM \$10,000-\$24,999
}

\author{
Anderman-Smith Operating Co. \\ Archer Daniels Midland Co. \\ Bird Oll Corporation \\ Burlington Northern Railroad \\ Combustion Engineering, Inc. \\ Copeland, Wickersham, Wiley \& Co. \\ John Harris IV \\ Holme Roberts \& Owens \\ MDU Resources Group, Inc. \\ Meridian Oll, Inc. \\ Mewbourne Oll Company \\ Public Service Indiana \\ Southern Company Services \\ State of Colorado \\ State of New Jersey \\ State of North Dakota \\ State of Wyoming \\ United Bank of Denver
}

U.S. Environmental Protection Agency

Xerox Financial Services

\section{CONTRIBUTIONS UP TO $\$ 10,000$}

\author{
American Electric Power \\ Banner Energy \\ EBASCO Services Incorporated \\ Edison Electric Institute \\ Electric Power Research Institute \\ General Atomics \\ PG\&E Enterprises \\ Prudential Foundation \\ Northern States Power Company \\ Shell Oil Company Foundation \\ Society of Independent Professional Earth Scientists \\ State of Oklahoma \\ U. S. Council for Energy Awareness \\ Xerox Foundation
}



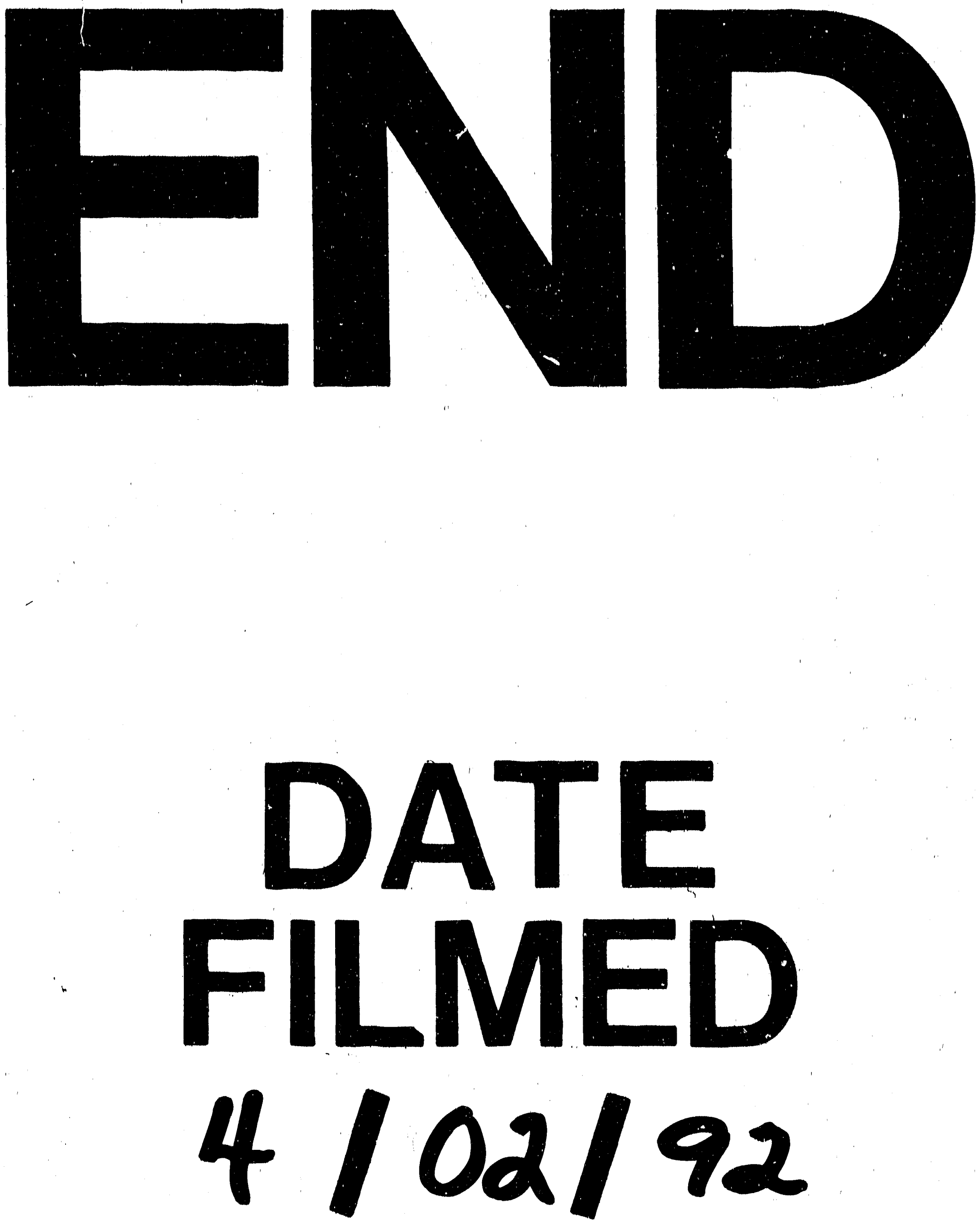

1 